\title{
Deglaciation of the northwestern White Mountains, New Hampshire
}

\author{
La déglaciation du nord-ouest des White Mountains, au New \\ Hampshire (E.U.A.) \\ Enteisung der nordwestlichen White Mountains, New \\ Hampshire
}

\author{
Woodrow B. Thompson, Brian K. Fowler et Christopher C. Dorion
}

Volume 53, numéro 1, 1999

Late Quaternary History of the White Mountains, New Hampshire and Adjacent Southeastern Québec

URI : https://id.erudit.org/iderudit/004882ar

DOI : https://doi.org/10.7202/004882ar

Aller au sommaire du numéro

\section{Éditeur(s)}

Les Presses de l'Université de Montréal

ISSN

0705-7199 (imprimé)

1492-143X (numérique)

Découvrir la revue

Citer cet article

Thompson, W. B., Fowler, B. K. \& Dorion, C. C. (1999). Deglaciation of the northwestern White Mountains, New Hampshire. Géographie physique et Quaternaire, 53(1), 59-77. https://doi.org/10.7202/004882ar
Résumé de l'article

Le mode de déglaciation du nord-ouest des White Mountains a fait l'objet de contro- verses depuis le milieu du XIX ${ }^{\mathrm{e}}$ siècle. Les premiers chercheurs ont supposé que le complexe morainique de Bethlehem dans le bassin de l'Ammonoosuc River avait été mis en place par la glace active au cours du recul du dernier Inlandsis. Au cours des années 1930, ce modèle de déglaciation a été remplacé par le concept selon lequel il y aurait eu stagnation simultanée sur une grande étendue et fonte de l'inlandsis du Wisconsinien supérieur. Les présents auteurs ont réétudié la Moraine de Bethlehem et appuient l'interprétation originelle selon laquelle il s'agit d'un ensemble de moraines terminales mises en place par une glace active. Ils ont aussi découvert d'autres ensembles morainiques d'âge similaire au nord-est, dans les bassins de Johns River et Israel River. Quelques dépôts de marge glaciaire, probablement de la même époque que celle du complexe morainique de Bethlehem, ont aussi été identifiés à l'ouest de Littleton. Le complexe morainique de Bethlehem et les dépôts équivalents dans les zones adjacentes ont été mis en place par récurrence et retrait oscillatoire du lobe de la vallée du Connecticut appartenant à l'Inlandsis laurentidien. Il s'agit de la récurrence de Littleton-Bethlehem. Les dates obtenues en Nouvelle-Angletterre et dans le Québec limitrophe laissent supposer que l'Inlandsis laurentidien s'est retiré de cette partie des White Mountains vers 12 500-12 000 ${ }^{14} \mathrm{C}$ BP. Les auteurs attribuent la récurrence à une refroidissement climatique de courte durée vers 12000 BP, pendant le Dryas ancien.
Tous droits réservés C Les Presses de l'Université de Montréal,1999

Ce document est protégé par la loi sur le droit d'auteur. L'utilisation des services d'Érudit (y compris la reproduction) est assujettie à sa politique d'utilisation que vous pouvez consulter en ligne.

https://apropos.erudit.org/fr/usagers/politique-dutilisation/ 


\section{DEGLACIATION OF THE NORTHWESTERN WHITE MOUNTAINS, NEW HAMPSHIRE}

Woodrow B. THOMPSON*, Brian K. FOWLER** and Christopher C. DORION"**, respectively Maine Geological Survey, 22 State House Station, Augusta, Maine 04333-0022 U.S.A.; Mount. Washington Observatory, P. O. Box 2310, North Conway, New Hampshire 03860 U.S.A. and Geological Services, 79 Bennoch Rd., Orono, Maine 04473 U.S.A.

\begin{abstract}
The mode of deglaciation in the northwestern White Mountains of New Hampshire has been controversial since the mid 1800 's. Early workers believed that active ice deposited the Bethlehem Moraine complex in the Ammonoosuc River basin during recession of the last ice sheet. In the 1930's this deglaciation model was replaced by the concept of widespread simultaneous stagnation and downwastage of Late Wisconsinan ice. The present authors reexamined the Bethlehem Moraine complex and support the original interpretation of a series of moraines deposited by active ice. We found other moraine clusters of similar age to the northeast in the Johns River and Israel River basins. Ice-marginal deposits that probably correlate with the Bethlehem Moraine also occur west of Littleton. The Bethlehem Moraine complex and equivalent deposits in adjacent areas were formed by readvance and oscillatory retreat of the Connecticut Valley lobe of the Laurentide Ice Sheet. This event is called the Littleton-Bethlehem Readvance. Throughout the study area, sequences of glaciolacustrine deposits and meltwater drainage channels indicate progressive northward recession of the glacier margin. Radiocarbon dates from nearby New England and Québec suggest that the ice sheet withdrew from this part of the White Mountains between about 12,500 and $12,000{ }^{14} \mathrm{C}$ yr BP. We attribute the LittletonBethlehem Readvance to a brief climatic cooling during Older Dyas time, close to $12,000 \mathrm{BP}$.
\end{abstract}

RÉSUMÉ Ladéglaciationdunord-ouestdes White Mountains, au New Hampshire (E.U.A.). Le mode de déglaciation du nord-ouest des White Mountains a fait l'objet de controverses depuis le milieu du XIX ${ }^{\mathrm{e}}$ siècle. Les premiers chercheurs ont supposé que le complexe morainique de Bethlehem dans le bassin de l'Ammonoosuc River avait été mis en place par la glace active au cours du recul du dernier Inlandsis. Au cours des années 1930, ce modèle de déglaciation a été remplacé par le concept selon lequel il y aurait eu stagnation simultanée sur une grande étendue et fonte de l'inlandsis du Wisconsinien supérieur. Les présents auteurs ont réétudié la Moraine de Bethlehem et appuient l'interprétation originelle selon laquelle il s'agit d'un ensemble de moraines terminales mises en place par une glace active. Ils ont aussi découvert d'autres ensembles morainiques d'âge similaire au nord-est, dans les bassins de Johns River et Israel River. Quelques dépôts de marge glaciaire, probablement de la même époque que celle du complexe morainique de Bethlehem, ont aussi été identifiés à l'ouest de Littleton. Le complexe morainique de Bethlehem et les dépôts équivalents dans les zones adjacentes ont été mis en place par récurrence et retrait oscillatoire du lobe de la vallée du Connecticut appartenant à l'Inlandsis laurentidien. II s'agit de la récurrence de Littleton-Bethlehem. Les dates obtenues en Nouvelle-Angletterre et dans le Québec limitrophe laissent supposer que l'Inlandsis laurentidien s'est retiré de cette partie des White Mountains vers 12 500-12 000 ${ }^{14} \mathrm{C}$ BP. Les auteurs attribuent la récurrence à une refroidissement climatique de courte durée vers $12000 \mathrm{BP}$, pendant le Dryas ancien.
ZUSAMMENFASSUNG Enteisung dernordwestlichen White Mountains, New Hampshire. Die Art des Abschmelzens in den nordwestlichen White Mountains von New Hampshire ist seit Mitte des 19. Jahrhunderts umstritten gewesen. Die ersten Forscher glaubten, dass aktives Eis die Bethlehem-Moräne-Einheit während des Rückzugs der letzten Eisdecke im Becken des Ammonoosuc-Flusses ablagerte. In den 30er Jahren des 20. Jahrhunderts wurde dieses Enteisungsmodell durch das Konzept einer gleichzeitigen weitflächigen Stagnation und Abwärtszehrung des Spät-Wisconsin-Eises ersetzt. Die gegenwärtigen Autoren haben die Bethlehem-Moräne-Einheit neu untersucht und stützen die ursprüngliche Interpretation einer Serie von Moränen, welche durch das aktive Eis abgelagert wurden. Sie fanden weitere Moränen-Einheiten ähnlichen Alters nordostwärts in den Becken von Johns River und Israel River. Eisrand-Ablagerungen, die wahrscheinlich mit der Bethlehem-Moräne korrelieren, treten auch westlich von Littleton auf. Die Bethlehem-Moräne-Einheit und entsprechende Ablagerungen in angrenzenden Gebieten wurden durch Rückvorsto $\beta$ und oszillatorischen Rückzug der Connecticut Tal-Lobe der laurentischen Eisdecke gebildet. Dies Ereignis nennt man den Littleton-Bethlehem-Rückvorsto $\beta$. Durch das ganze erforschte Gebiet hindurch weisen Folgen glaziallimnischer Ablagerungen und Schmelzwasser-DrainageRinnen auf einen Rückzug des Gletscherrands in Richtung Nordwest. Radiokarbondaten vom nahen Neu-England und Québec legen nahe, dass die Eisdecke sich von diesem Teil der White Mountains zwischen etwa $12500-12000{ }^{14} \mathrm{C}$ Jahren v.u.Z. zurückzog. Wir schreiben den Littleton-Bethlehem Rückvorsto $\beta$ einer kurzen Klima-Abkühlung während des älteren Dryas zu, um 12000 v.u.Z.

Manuscrit reçu le 22 mai 1998 ; manuscrit révisé accepté le 14 décembre 1999

* E-mail address: woodrow.b.thompson@state.me.us

${ }^{* *}$ E-mail address: bfnar@cyberportal.net

${ }^{* * *}$ E-mail address: cdorion@bangornews.infi.net 


\section{INTRODUCTION}

Many geologists have investigated the glacial history of the White Mountains (see historical review by W. B. Thompson, this volume). The early visits of Louis Agassiz, Edward Hitchcock, and Charles Lyell stimulated interest in the region. Studies in the northwestern White Mountains, between the Presidential Range and the Connecticut River, led to controversy over the relative importance of local (alpine) versus continental glaciation in this part of New Hampshire (Goldthwait, 1916). Later debate concerned the style of deglaciation - whether there was active-ice retreat or wholesale stagnation and accompanying downwastage of the ice sheet (Goldthwait, 1938; Lougee, 1940). The concept of stagnation and downwastage in New England was dominant from the 1930's until the late 1900's.

The application of the morphosequence concept in central to southern New England (Koteff and Pessl, 1981) showed that systematic ice-margin retreat occurred in many areas where end moraines are scarce or absent. This paradigm shift forced a reevaluation of the stagnation theory throughout the region. Recent descriptions of moraines and glaciotectonic structures in the northeastern White Mountains have shown that active ice persisted during deglaciation in areas that were topographically favorable for sustained glacial flow (e.g. Gerath, 1978; Gerath et al., 1985; and Thompson and Fowler, 1989).

The present study reexamines the Bethlehem Moraine complex, which is a belt of linear and hummocky glacial deposits in the towns of Bethlehem and Littleton. This complex was at the center of debate over the mode of deglaciation in the White Mountains, having been used by proponents of both active-ice and stagnation retreat to support their views. We also investigated other deposits to the east and west that may have formed at the same time as the moraines in Bethlehem and Littleton. These include a thick section of glacial sediments next to Comerford Dam in the Connecticut River valley, which previous workers have attempted to correlate with the Bethlehem Moraine.

The Bethlehem Moraine complex is located in the central Ammonoosuc River basin. This river originates on the side of Mount Washington in the Presidential Range and flows west to Littleton, whence it takes a southwesterly course to the Connecticut River (Fig. 1). The deglaciation history of the Ammonoosuc basin is closely related to that of neighboring river basins to the north. The Israel River drains part of the northern Presidential Range and flows northwest to the Connecticut River at Lancaster. Between the Ammonoosuc and Israel Rivers is the Johns River, a shorter stream that flows northwest through Whitefield and enters the Connecticut River in Dalton (Fig. 1).

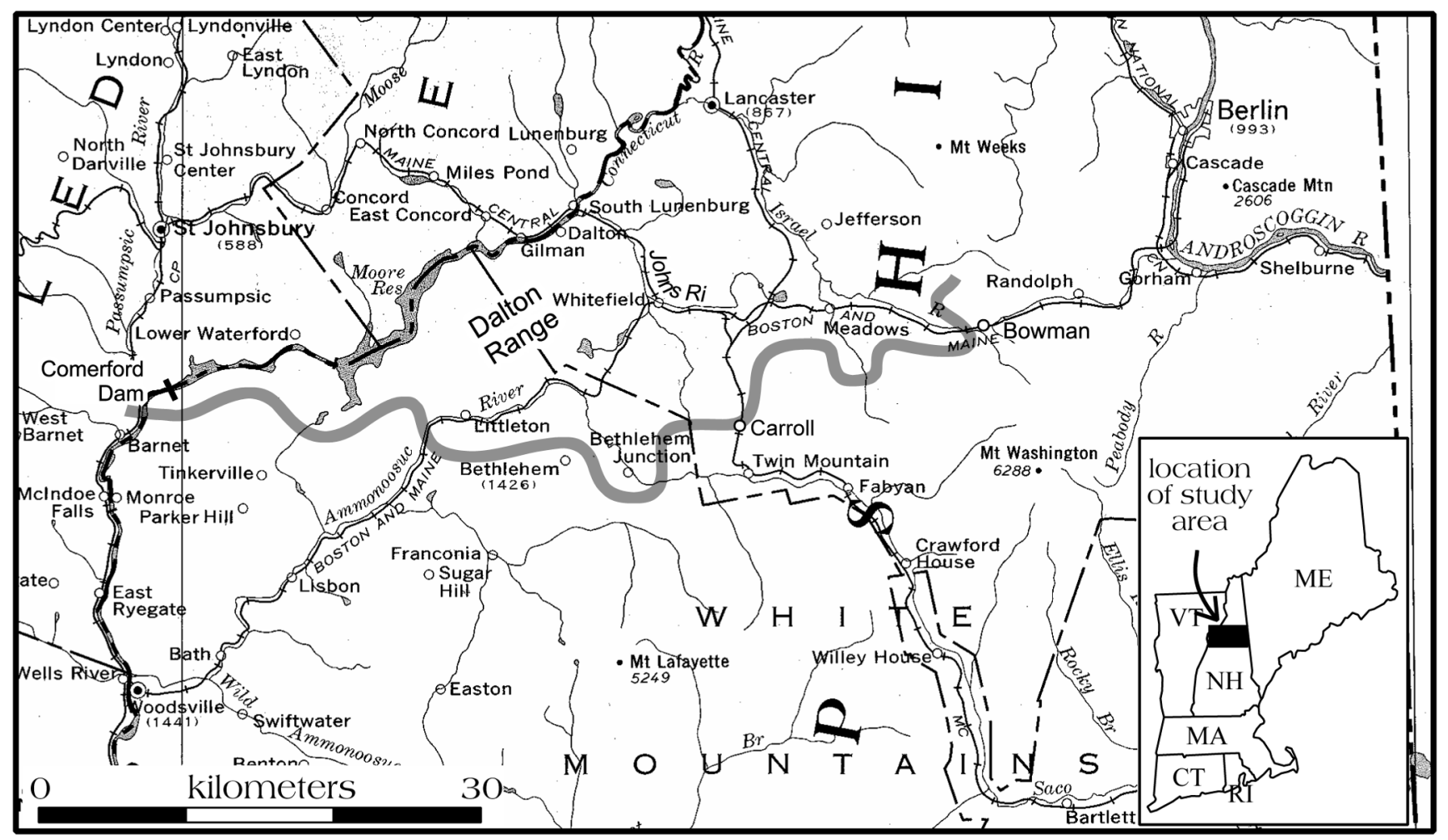

FIGURE 1. Map of northern White Mountain region, showing principal towns and rivers in New Hampshire and adjacent Vermont. Thick gray line is inferred southern limit of Littleton-Bethlehem Readvance.
Région du nord des White Mountains, montrant les principales villes et rivières du New Hampshire et du Vermont attenant. Le trait gris large marque la limite méridionale de la récurrence de Lettleton-Bethlehem. 
Damming of the west-draining Ammonoosuc, Israel, and Johns River valleys by the receding Late Wisconsinan ice sheet formed a series of ephemeral lakes (Lougee, n.d., 1939). Northward recession of the ice sheet opened progressively lower outlets for these lakes. We used the positions and elevations of the spillway channels, together with moraines and ice-contact deltas, to help reconstruct the sequence of deglaciation.

\section{PREVIOUS WORK}

Early investigations in the study area were concerned with the clusters of drift ridges and hummocks in the Ammonoosuc valley that eventually became known as the Bethlehem Moraine. Louis Agassiz published the first observations on these deposits following his 1847 visit to the White Mountains. Along a road just north of Bethlehem village, he claimed to have seen "... sixteen terminal moraines in a tract of about two miles. Some of these moraines are as distinct as any I know in Switzerland" (Agassiz, 1870, p. 164). It has not been so obvious to other geologists that moraines exist in the area described by Agassiz, and confusion over what he saw probably contributed to the skepticism of later workers regarding the entire moraine complex. Agassiz thought that the morphology and boulder provenance of moraines in the Bethlehem area proved they were deposited by a local glacier flowing north from the vicinity of Mount Lafayette in Franconia.

Charles Hitchcock (1878a) agreed with Agassiz's theory of local ice depositing the moraines from the south. Upham likewise concurred with this theory and formally named the Bethlehem Moraine (Upham, 1904, p. 12). However, he believed that the source was a larger ice cap remaining over the high mountains after recession of the continental ice sheet. Upham could not distinguish the sharp moraine ridges reported by Agassiz, and he characterized the Bethlehem Moraine as being the "continental type". Upham's description is close to what the present authors have seen: "The material of this belt is chiefly till, with some modified drift, as kames, or knolls of gravel and sand. The contour is very irregular, in multitudes of hillocks and little ridges, grouped without order or much parallelism of their trends. Everywhere in and upon these deposits boulders abound,... being far more plentiful than in and on the adjoining smoother tracts of till throughout this region" (Upham, 1904, p. 11-12).

James Goldthwait (1916) reinterpreted the Bethlehem Moraine. Agassiz's model was found to be flawed because it proposed a topographically unrealistic ice-flow path, lacked adequate documentation of northward erratic transport, and was not supported by striation evidence. Goldthwait pointed to the lack of recessional moraines in the Franconia Range as another problem with Agassiz's and Upham's local-ice models. He said that the geometry, provenance, and associated lake sediments favor deposition of the Bethlehem Moraine from the north by the continental ice sheet. Goldthwait's 1916 paper included the first map of the Bethlehem Moraine (Fig. 2). He also named glacial Lake Ammonoosuc, which was impounded by the retreating glacier margin in the Ammonoosuc Valley.

Ernst Antevs (1922) inferred from his Connecticut Valley varve records that a glacial readvance occurred west of Littleton, in the area where Comerford Dam is now located (Fig. 1). He suggested that this readvance might correlate
FIGURE 2. Part of map by J.W. Goldthwait (1916), showing inferred moraines (stippled areas) in Bethlehem, New Hampshire. Arrows indicate ice-flow direction at striation localities.

Une partie de la carte de J.W. Goldthwait (1916) montrant les moraines (zones en pointillés) à Bethlehem, au New Hampshire. Les flèches donnent la direction des glaces donnée par les stries.

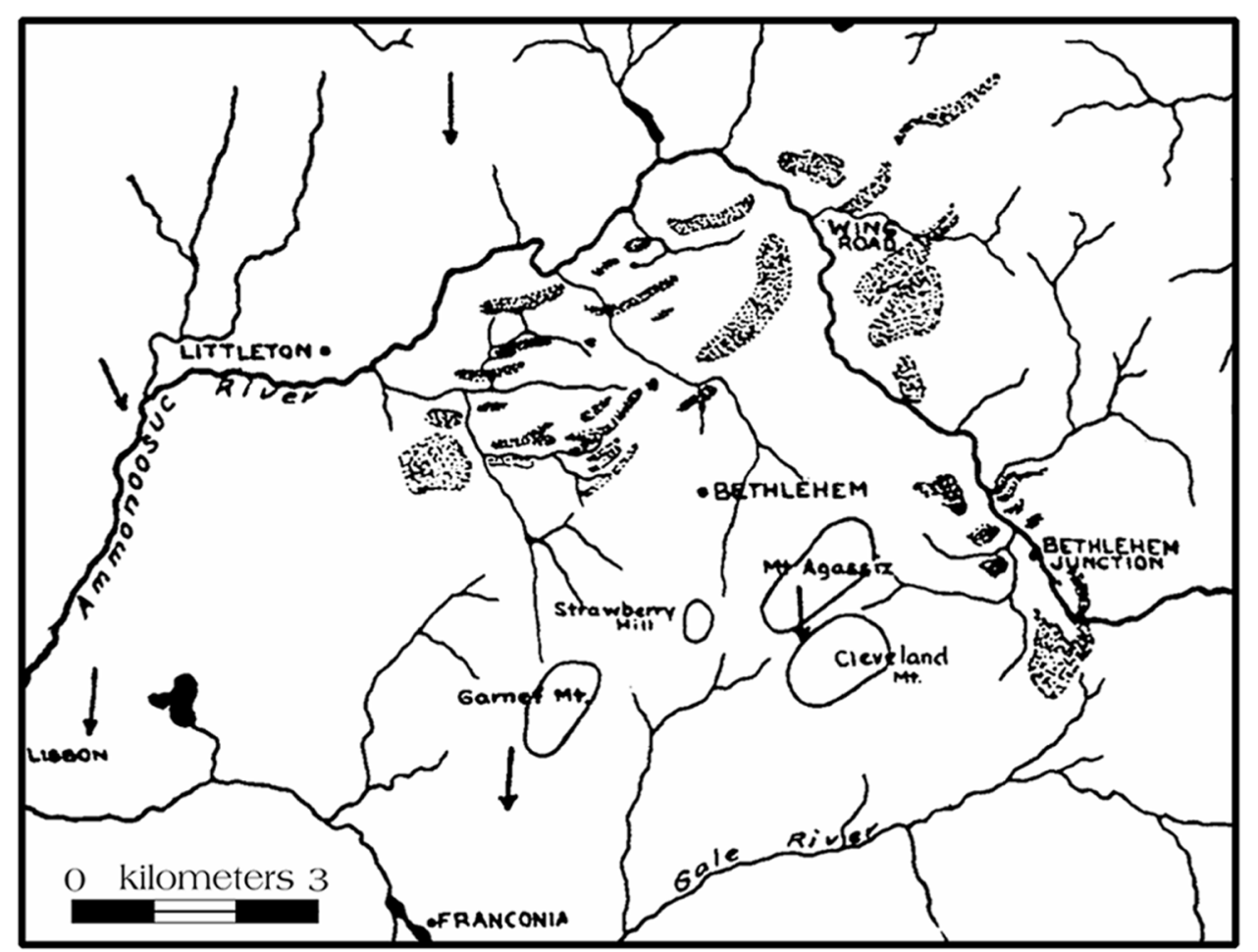


with the Bethlehem Moraine. Crosby (1934b) made the same correlation, supported by the two-till stratigraphy that he found at the dam site. Crosby further suggested that the ice margin associated with the Bethlehem Moraine could be traced eastward to the head of a delta at Carroll (Fig. 1). From there, it supposedly continued northeast and correlated with till deposits that overlie lake sediments in the Peabody River sections south of Gorham.

In 1930, Richard Lougee assisted Goldthwait in a gravel inventory funded by the New Hampshire Highway Department. He was assigned to map several 15 -minute quadrangles in the White Mountains. Lougee (n.d.) prepared a manuscript that included a wealth of new information on glacial deposits, lakes, and meltwater drainage routes in the region. A copy of this paper resides in the Special Collections of the Dartmouth College Library. It is unfortunate that it was never published, since it contains the first analysis of the stages of glacial Lake Ammonoosuc and corresponding spillways.

When Goldthwait became an advocate of ice retreat by pervasive glacial stagnation, he dismissed the Bethlehem Moraine as simply being a "zone of massive kettled outwash" (Goldthwait, 1938, p. 349). However, Lougee (1940) continued to defend the active-ice deglaciation model and the existence of moraines in the Bethlehem area.

\section{BETHLEHEM MORAINE COMPLEX}

\section{MORAINES IN BETHLEHEM AND LITTLETON}

The deposits traditionally called the Bethlehem Moraine comprise hummocks and ridges of glacial sediments in the Ammonoosuc River valley. The morainic belt does not have a sharply defined boundary. As originally mapped by J.W. Goldthwait (1916), it is concentrated mostly within $5 \mathrm{~km}$ west, north, and east of Bethlehem village (Fig. 2). We call this group of deposits the Bethlehem Moraine complex, because it includes many individual deposits and not just a single well-defined moraine ridge.

The western part of Figure 3 shows the topography of the area that early workers included in the Bethlehem Moraine. This map is from the $1: 62,500$ Whitefield quadrangle, which represents some landforms more accurately than the recent 1:25,000 Bethlehem quadrangle. One can understand why Upham (1904) called the Bethlehem deposits a "promiscuous morainic belt". Nevertheless, many ridges in the moraine complex show a consistent east to northeast trend as noted by Goldthwait (1916).

In field-checking this area, we considered a "moraine" to be a single-crested ridge of glacial sediment inferred to have been deposited at or near the ice margin and parallel to it. The moraine ridges in Bethlehem range in height from $3 \mathrm{~m}$ to over $30 \mathrm{~m}$, and are up to $1300 \mathrm{~m}$ long. Large boulders of granite and gneissic granite are abundant on the surfaces of moraine segments. These boulders probably were derived from the Devonian Alderbrook Pluton immediately to the north (Lyons et al., 1997; Moench et al., 1995). The eleva- tions of the moraines suggest that many of them were deposited subaqueously in glacial Lake Ammonoosuc (described below).

Our observations do not agree with Goldthwait's contention that "the morainic ground is chiefly composed of sands, gravels, and cobbly boulder beds, with the finer sediment predominating" (Goldthwait, 1916, p. 272). The exposures we have seen in pits and road cuts show that the clearly defined moraine ridges are mostly composed of silty-sandy till, locally containing lenses of sand, gravel, and silt. Much of the sand and gravel that Goldthwait noted probably was deposited in glacial Lake Ammonoosuc or in early postglacial Ammonoosuc River terraces.

Upham (1904) and Lougee (1940) briefly mentioned other prominent moraines west of Bethlehem. We verified their reports and found that the Bethlehem Moraine complex continues across the hillside on the south side of the town of Littleton (Fig. 4). This area contains till ridges that are 6-36 $\mathrm{m}$ high and 100-500 m or more in length. Large boulders are particularly abundant on the moraines at higher elevations, on the hillside southwest of U. S. Route 302 (Thompson et al., 1996). There are a few other scattered moraines in the western part of Littleton that may correlate with the Bethlehem Moraine complex. These include an ENE-trending till ridge, over $30 \mathrm{~m}$ high, located just south of Slate Ridge Road and east of Mullikin Brook (evident on Littleton 1:24,000 quadrangle), and some probable moraines near the south end of Moore Reservoir (Fig. 1) in the Connecticut River valley.

\section{STRATIGRAPHIC RELATIONSHIPS}

Recent exposures in three borrow pits showed the relationship of the Bethlehem Moraine complex to other glacial and lacustrine deposits. These sites are the Dodge and Marvin Pits in Littleton (Fig. 4), and the Wedick Pit in Bethlehem (Fig. 3). The Marvin Pit exposes lodgement till that probably was deposited during the Late Wisconsinan glacial maximum. The Dodge Pit, located uphill to the south of the Marvin Pit, formerly exposed a cross section through a till ridge in the Bethlehem Moraine complex. The Wedick Pit contains a sequence of till overlain by glacial Lake Ammonoosuc sediments and river deposits.

\section{Marvin Pit}

The Marvin Pit is located in a terrace on the south side of the Ammonoosuc River. A $5 \mathrm{~m}$ section of silty-sandy till is exposed on the uphill (southeast) side of the pit. This till is dark gray and nonoxidized (5Y-4/1). It is generally nonstratified but contains a few sand lenses. The till is moderately compact with weak fissility. Pebble and cobble-size clasts are abundant, including numerous faceted and striated stones (29\% of stone count). There are scattered boulders, many of which are white granite or granodiorite. The matrix is carbonate-bearing, and carbonate coatings are very common on clast surfaces. 


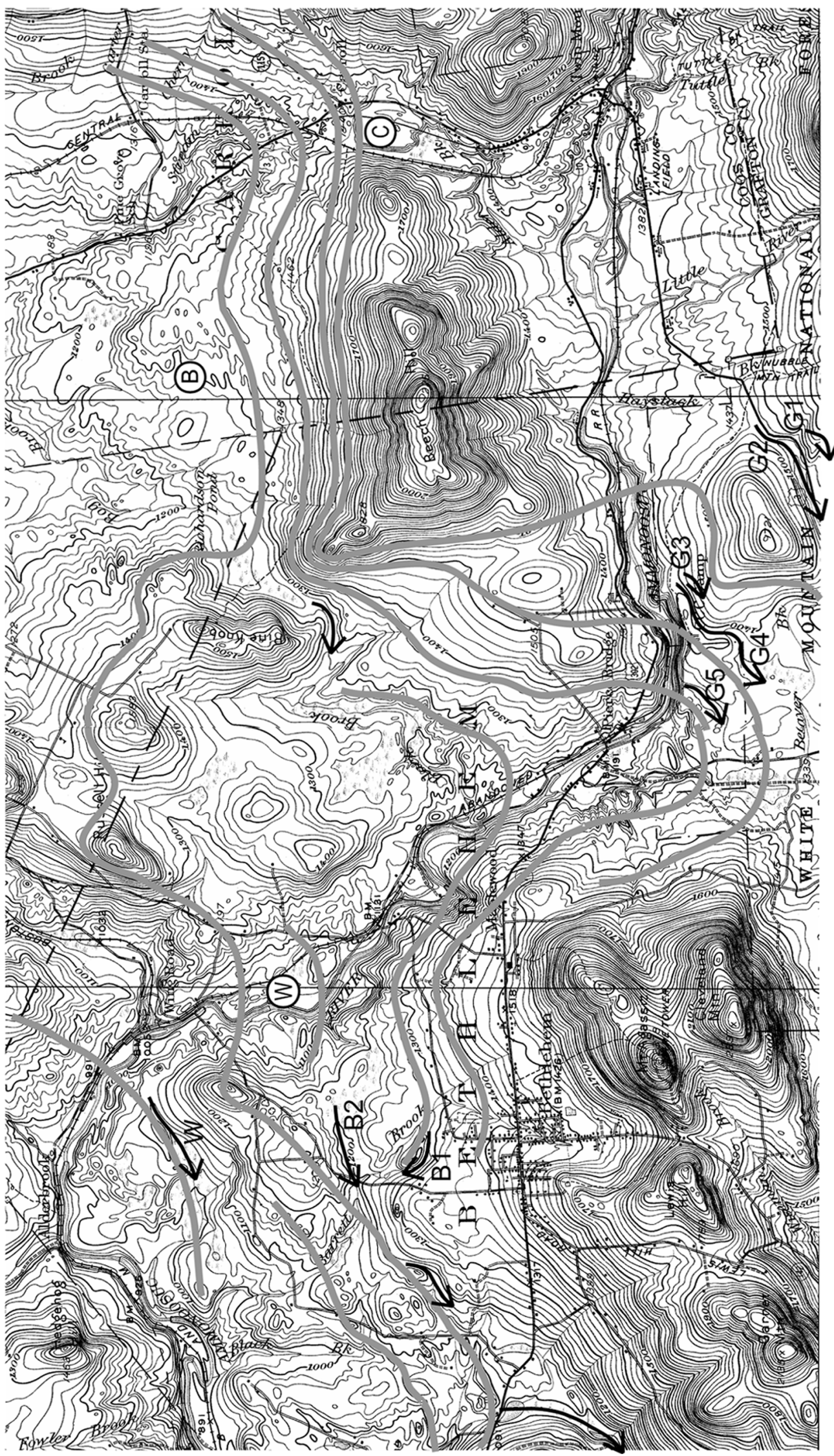

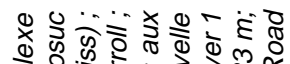

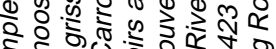

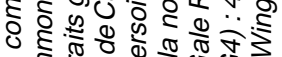
उ

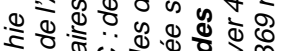

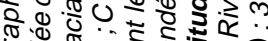

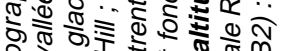
O. ช

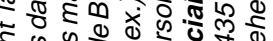

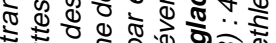
ㄷำ

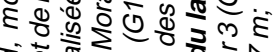

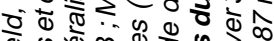

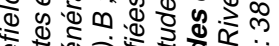

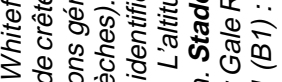
\& 0 :

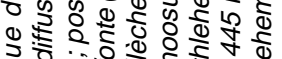
ज्ञ है क के

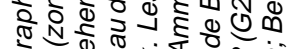
कह

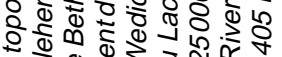
०

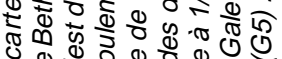

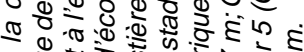

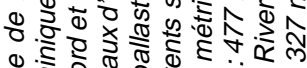
类

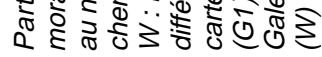

Ð

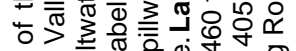

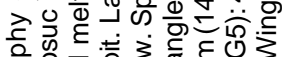
匹

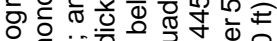
응 हो $\ddot{2} \cong$

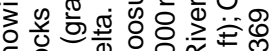

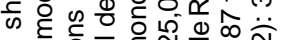

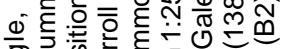

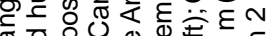

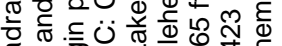

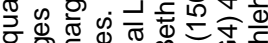
$\Phi$.은

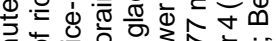

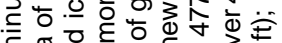
它焉步 응 क

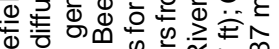
的积 交递 ๑ है

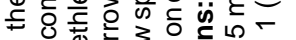

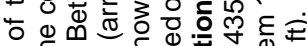

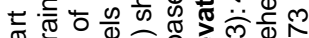

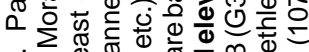
m $\varepsilon$ 过 㟧 든 


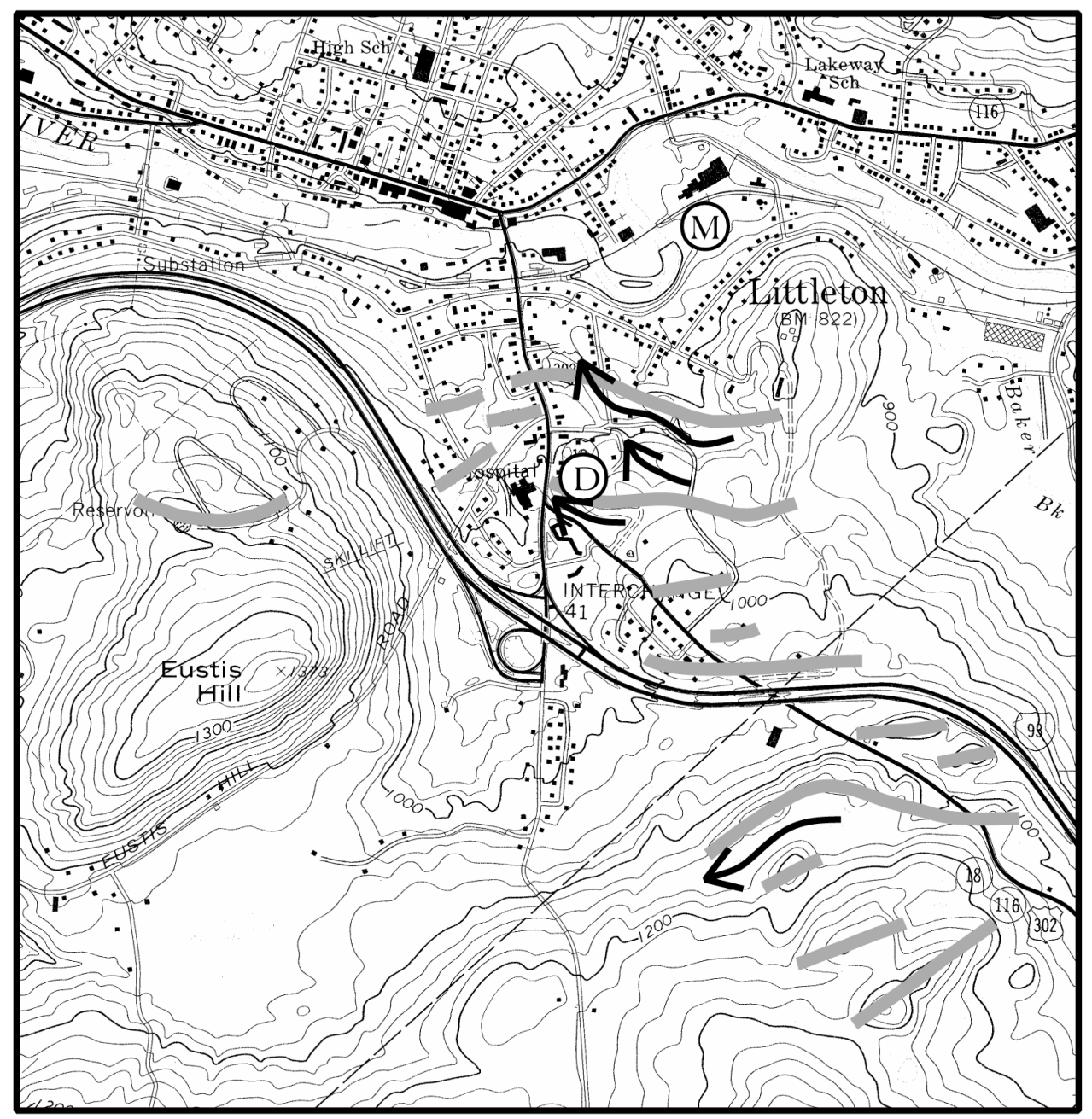

FIGURE 4. Topographic map of Littleton area, showing moraine ridges forming western part of Bethlehem Moraine complex (thick gray lines) and meltwater channels (arrows). D:Dodge Pit. M: Marvin Pit.

Carte topographique de la région de Litttleton, montrant les crêtes morainiques quicomposent la partie ouest du complexe morainique de Bethlehem (traits gris épais) et les chenaux d'écoulement de l'eau de fonte (flèches). $D$ : Ballastière de Dodge ; $M$ : ballastière de Marvin.

Bedrock is exposed along the river bank just southwest of the Marvin Pit, at an elevation of $244 \mathrm{~m}$. These outcrops belong to the metasedimentary member of the Ordovician Ammonoosuc Volcanics (Lyons and others, 1997). Glacial striations on the ledges indicate ice flow directions of $125-173^{\circ}$ with the more easterly trends being older. Upslope from these outcrops, a landslide scar exposes the same till unit seen in the Marvin Pit. Here the lodgement till is overlain by $30 \mathrm{~cm}$ of sand, followed by sandy ablation till that appears identical to much of the surface till throughout the area. There is no significant weathering profile or other indication of a long hiatus between deposition of the till units.

A fabric was obtained from a NE-trending till section in the Marvin Pit. We measured the orientation of 52 stones with long axes $>2.5 \mathrm{~cm}$ and long:intermediate axial ratios of at least 2:1. The fabric data show a strong preferred orientation in the $320-330^{\circ}$ range (Fig. 5). This orientation suggests ice flow to the southeast, in agreement with regional striation trends and streamlined hills across northern New Hampshire and western Maine that presumably formed during the Late Wisconsinan glacial maximum (Goldthwait et al., 1951;
Thompson and Borns, 1985). Considering its structure, faceted and striated stones, and strong fabric, the till in the Marvin Pit is considered to be a lodgement facies.

A count of 100 pebbles $(2-10 \mathrm{~cm})$ from the Marvin Pit showed that the three most abundant rock types and their inferred sources (from Moench et al., 1995, and Billings, 1935) are: (1) light-gray, medium to coarse-grained, variably altered granodiorite from the Highlandcroft Plutonic Suite $(30 \%)$; (2) dark-gray, fine-grained, non-calcareous metapelite from the Littleton Formation (21\%); and (3) greenish-gray, fine-grained, calcareous and non-calcareous rocks attributed to the Ammonoosuc Volcanics (15\%) (Table I). There is also a significant percentage of calcareous metapelites, probably from the Fitch Formation.

\section{Dodge Pit}

The Dodge Pit exposed sandy, nonoxidized till comprising an east-west moraine ridge up to $12 \mathrm{~m}$ high, with a crest elevation of approximately $287 \mathrm{~m}$. The till is olive-gray (5Y-5/2), slightly compact, and stony. Most of the stones are pebbles 
TABLE I

Stone counts from Marvin and Dodge Pits, Littleton, $\mathrm{NH}$

\begin{tabular}{lcc}
\hline Rock type & Marvin Pit & Dodge Pit \\
\hline Biotite granite / granodiorite & 5 & 19 \\
Other granitic rocks & 8 & - \\
Granodiorite (Highlandcroft Plutonic Suite) & 30 & 17 \\
Diorite & - & 6 \\
Metavolcanics (Ammonoosuc Volcanics) & 15 & 7 \\
Metapelite (Littleton Fm.) & 21 & 20 \\
Calcareous metapelite (Fitch Fm.?) & 7 & - \\
Quartzite & 2 & 8 \\
Phyllite (Ammonoosuc Volcanics- & - & 4 \\
sedimentary facies) & & \\
High-grade schist and gneiss & 8 & 14 \\
(Albee / Rangeley Fm.) & & \\
Other & 4 & 5 \\
Total & 100 & 100 \\
\hline
\end{tabular}

and cobbles. Boulders 1-2 $\mathrm{m}$ in diameter are fairly common on the surface but sparse within the moraine. Twenty-two percent of the till stones are striated or faceted.

A face in the Dodge Pit exposed a vertical cross section through the moraine (Fig. 6). The proximal and central parts of this section showed many thin sand lenses dipping north toward the former ice margin (Fig. 7). The lenses apparently resulted from deformation of the morainal sediments by ice shove. Some of them were fragmented and internally sheared, and discoidal stones in the proximal part of the section were oriented parallel to the sand lenses. Exposures in the distal part of the moraine revealed pods of washed sand and gravel, and a prominent meltwater channel is located just south of the ridge (Fig. 4).

We obtained a fabric from 41 stones in a north-south till section in the proximal part of the moraine (Fig. 5). This fabric is more dispersed than the fabric from the Marvin Pit, but the vector mean of the rose diagram $\left(8^{\circ}\right)$ generally parallels late-glacial S to SSW ice-flow recorded by striations in many places near Littleton. It is also normal to the axis of the moraine. Some of the maxima in the Dodge Pit fabric are transverse to ice-flow, perhaps due to rolling of the stones before deposition.

The stone count from the Dodge Pit shows a provenance that is different from the Marvin Pit (Table I). Of the rock types that could be identified, slaty metapelites attributed to the Littleton Formation are present in nearly equal abundance (20\%). The percentages of Highlandcroft granodiorite and Ammonoosuc Volcanics at the Dodge Pit drop to $17 \%$ and $7 \%$, respectively, and there are no calcareous rocks. Biotite-rich white granitic rock is much more abundant (19\%), probably originating from the Remick pluton just north of the Ammonoosuc River in Littleton (Moench et al., 1995; Billings, 1935). A distinctive crenulated phyllite in the Dodge Pit is identical to phyllite from the riverside ledges near the Marvin Pit.
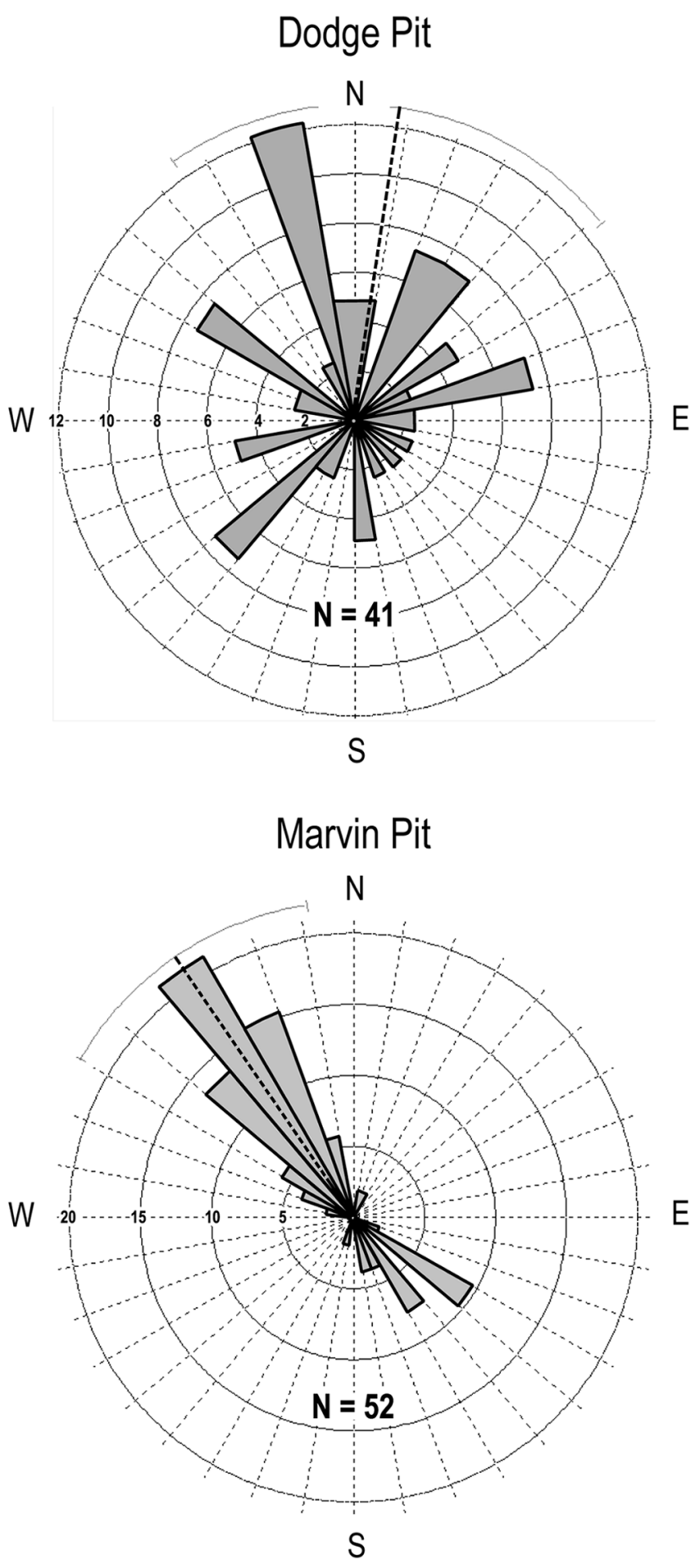

FIGURE 5. Rose diagrams showing till fabrics from Marvin and Dodge Pits in Littleton. Radius numbers are percentages of total. Heavy dashed lines are vector means.

Diagramme circulaire montrant l'orientation des tills dans les ballastières de Marvin et de Dodge. Les chiffres du rayon représentent des pourcentages. Les deux lignes noires brisées représentent la moyenne des vecteurs. 


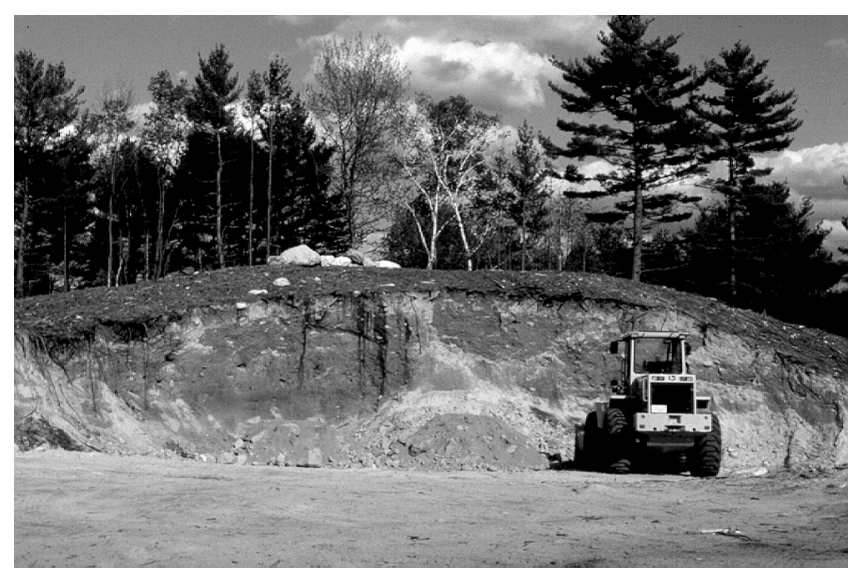

FIGURE 6. Cross section through moraine ridge in Dodge Pit. View to east.

Coupe dans la crête morainique dans la ballastière de Dodge (vue vers l'est).

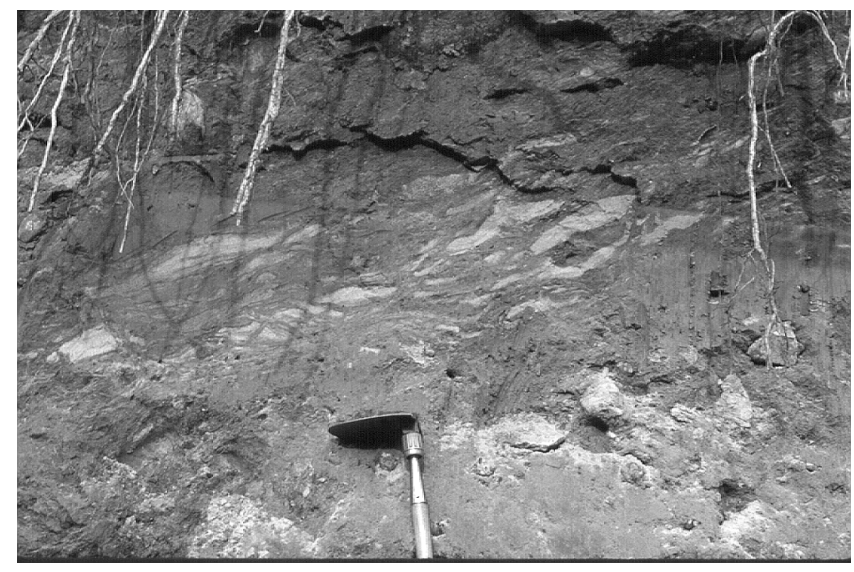

FIGURE 7. Close-up of proximal part of section seen in Figure 6. Note sheared sand lenses dipping north, toward former position of glacier margin.

Gros plan de la partie proximale de la coupe de la figure 6. À noter les lentilles de sable cisaillées, inclinées vers le nord, là où se trouvait la marge glaciaire

While some of the rock types in the Dodge Pit have uncertain origins, several of the schist and gneiss samples are distinguished by the presence of sillimanite or staurolite. Rocks of such high metamorphic grades have been mapped only in a narrow belt north-northwest of here. Sillimanite-bearing rocks are limited to the Miles Mtn. area in North Concord, Vermont, where they were included with the Albee Formation by Eric and Dennis (1958), and later assigned to the Rangeley Formation by Moench et al. (1995). In summary, comparison of the above stone counts (Table I) with regional geologic mapping by Moench et al. (1995) suggests a more northern source for till in the Dodge Pit, in contrast to a northwesterly provenance for lodgement till in the Marvin Pit. This inference is consistent with fabric data, orientation of the local end moraines, and regional bedrock striation trends (see below).

The moraine at the Dodge Pit differs in some respects from other nearby moraines (particularly the large high ridges south of Route 302). It is less bouldery on the surface; and the shear strucures, faceted and striated clasts, and paucity of ice-marginal indicators suggest a subglacial environment. This and other moraines close to the valley bottom in Littleton may have been formed by squeezing of till into subglacial crevasses near the ice margin, rather than being true end moraines. The meltwater channels in front of these moraines (Fig. 4) probably formed subaerially at the edge of the ice sheet, although they may have been cut after the moraines were deposited. A late stage of glacial Lake Ammonoosuc probably occupied the valley upstream from Littleton during ice retreat, but there is no indication that the moraines at Littleton were deposited subaqueously.

\section{Wedick Pit}

The Wedick sand and gravel pit extends east-southeast from Wing Road in Bethlehem (Fig. 3). It is located in an Ammonoosuc River terrace at an elevation of about $324 \mathrm{~m}$. The lowest stratigraphic unit in the pit is a very compact gray till, exposed in a trench in the pit floor. According to the owner, both till and clay were excavated from this trench, indicating the presence of glaciolacustrine sediments and/or waterlaid till. Many large boulders (to $3 \mathrm{~m}$ ) occurred on the surface of the till, but have been greatly reduced in number by recent excavations. Most of them are white to pink granite and gneissic granite derived from the Alderbrook Pluton to the north and northwest (Moench et al., 1995; Lyons et al., 1997).

The west end of the pit exposes laminated diamict consisting of alternating sandy and muddy layers with scattered pebbles and cobbles. Sections on the south side of the pit show $2.6 \mathrm{~m}$ of fluvial sand and gravel with cross-bedding dipping NNW (river-terrace alluvium). This unit overlies $2+m$ of laminated diamict (waterlaid till) with lenses of silt and sand. The uppermost $1.4 \mathrm{~m}$ of the till is greatly deformed. Judging from these exposures, at least the upper part of the till was deposited in the presence of abundant meltwater and probably in a glacial lake. We infer that this waterlaid till accumulated as debris flows where the Late Wisconsinan ice margin stood in glacial Lake Ammonoosuc, and then was locally deformed by ice shove. The many large boulders were dumped off the edge of the glacier, and are the equivalent of the boulder fields covering much of the Bethlehem Moraine complex.

Elsewhere in the Wedick Pit, exposures of lacustrine deltaic sand have foreset beds indicating water flow to the north. This delta was deposited by the early Ammonoosuc River flowing into one of the final stages of Lake Ammonoosuc (see below). The youngest unit in the Wedick Pit is fluvial sand and gravel that overlies till in some places and deltaic sediments in others. It is a late-glacial or early postglacial terrace deposit formed by the Ammonoosuc River.

\section{REGIONAL ICE-FLOW DIRECTIONS}

There are virtually no bedrock exposures within the Bethlehem Moraine complex, but striated outcrops in surrounding areas of Bethlehem and Littleton indicate southward ice-flow directions mostly in the range of $170-190^{\circ}$ (Hitchcock, 1878b, 1905; Goldthwait, 1916; Goldthwait et al., 1951). J.W. Goldthwait's map (Fig. 2) shows a few representative exam- 
ples of the southward flow. We have recorded striation trends in this area ranging from $125^{\circ}$ to $203^{\circ}$, and varying as much as $48^{\circ}$ at one locality. In the few places where we could determine relative ages of multiple striation sets, the striations trending south to south-southwest are usually youngest.

Hitchcock (1905) reported several localities in Littleton where striations have a more pronounced south-southwest orientation of around $200^{\circ}$. However, we found only one place in this town where the azimuths exceed $190^{\circ}$. On ledges next to athletic fields at White Mountain School, striation trends are mostly in the range $190-203^{\circ}$. Hitchcock attributed the SSW-trending striations to late-glacial ice flow, subsequent to the southeast flow that occurred during the glacial maximum. Our observations support this conclusion.

While striations in Littleton are generally normal to local east-west moraines, some of the moraine ridges between Littleton and Bethlehem have east-northeast trends that are oblique to nearby striations. Lougee (n.d.) noted this disparity and suggested that the latter moraines formed along the eastern side of a receding ice tongue. The local northeast trend of the Ammonoosuc Valley probably helped determine the orientation of the ice margin in this area. Just north of Bethlehem, we found striations trending $174-185^{\circ}$ on the north side of the Ammonoosuc River, and $178-179^{\circ}$ on the crest of Dalton Mountain. These data show that late-glacial southward ice flow crossed both the high hills and valley floor north of the Bethlehem Moraine complex.

Striations between Littleton and the Connecticut River likewise indicate generally southward ice flow. Most striations seen in this area trend between $170^{\circ}$ and $190^{\circ}$, though a few are more southeasterly. South-trending striations also occur in many places farther south in the Connecticut River basin (Goldthwait et al., 1951), so they are not associated exclusively with the Bethlehem Moraine complex.

\section{CORRELATIONS OF BETHLEHEM MORAINE COMPLEX WITH DEPOSITS IN ADJACENT AREAS}

\section{CONNECTICUT RIVER VALLEY}

Exposures of multiple till units and deformed lake sediments less than $20 \mathrm{~km}$ west of Littleton indicate glacial oscillations that may correlate with deposition of the Bethlehem Moraine complex. These sections are located next to Comerford Dam in the Connecticut River valley, on the border between Monroe, $\mathrm{NH}$, and Barnet, VT (Fig. 1). The dam is at the downstream (west) end of a part of the valley that was called "Fifteen-Mile Falls" prior to impoundment. Striations at various elevations on both sides of the river near the dam trend $180-190^{\circ}$. We attribute the southward ice flow in this area to the Connecticut Valley lobe of the Late Wisconsinan ice sheet. However, a well-developed $183^{\circ}$ set on ledges in front of the dam is presumed to be older, since these striations predate the adjacent "lower till" described by Crosby (1934b).

As Late Wisconsinan ice receded from this area, glacial Lake Hitchcock expanded up the Connecticut Valley at least as far as Woodsville; and either this lake or a lower stage of the same water body reached the present location of Comerford Dam (Ridge et al., this volume). The surface elevation of the lake was at least 244 m southwest of Littleton (Koteff and Larsen, 1989). Antevs (1922) measured varve sections downvalley from the dam site, and correlated them with his "normal curve" that documented the varve sequence for the Connecticut Valley. His Locality 85 (just below the dam on the Vermont side of the river) showed a delay of about 280 years in the onset of varve deposition, relative to Locality 86 a short distance downvalley. Thus, Antevs proposed a halt in ice retreat of this duration, which he tentatively correlated with the Bethlehem Moraine to the east.

Test borings and surface exposures during construction of Comerford Dam in 1928-1930 provided much new information on the local stratigraphy (Crosby, 1934a). In the bluff on the New Hampshire side of the valley, Crosby (1934a, b) recorded two till units separated by thrust-faulted sand and gravel. Figure 8 shows Crosby's site map and stratigraphic cross section along the east embankment of the dam.

Crosby discussed the oxidation and carbonate-leaching profiles of the tills. He concluded that the time interval between deposition of the tills was short, and that both tills were deposited by the most recent glaciation. Crosby proposed that after its initial recession, the ice sheet readvanced westward down the Connecticut Valley, into a proglacial lake, and incorporated sandy lake sediments into the upper till. He correlated this readvance with the readvance that deposited the Bethlehem Moraine (Crosby, 1934b).

In 1933 Lougee observed a new section next to the concrete wall bordering the spillway channel on the Vermont side of Comerford Dam (Fig. 8). This excavation showed about $2 \mathrm{~m}$ of deformed varves, underlain by $5 \mathrm{~m}$ of stony till and overlain by a thin remnant of "material resembling till". Lougee correlated this varve section with Antevs' normal curve, and found that the varves recorded 119 years between initial deglaciation and the "readvance at Littleton". Based on the number of varves that were missing (relative to nearby sections), he concluded that the readvance itself had a duration of 151 years (Lougee, 1935).

\section{Mill Brook Section}

The sections described by Crosby and Lougee are now mostly concealed, and we could not find original field notes or photographs showing details of what these earlier workers had seen. Crosby's engineering reports indicate that his stratigraphic section probably was compiled from test borings and surface exposures, rather than a single continuous exposure (Crosby, 1928, 1929). Ridge et al. (1996) recently found a complex till section south of Comerford Dam (Fig. 9). This $45-\mathrm{m}$ section is located on the east side of Mill Brook on Crosby's map (Fig. 8; the brook is given other names on U.S.G.S. topographic maps). We describe the section in detail because it is the only contemporary till exposure that may link the stratigraphy at the dam site to the Bethlehem Moraine complex. Ridge et al. (1996, this volume) have investigated the varve chronology in this area and provide a further linkage with the readvance in Littleton and Bethlehem. 

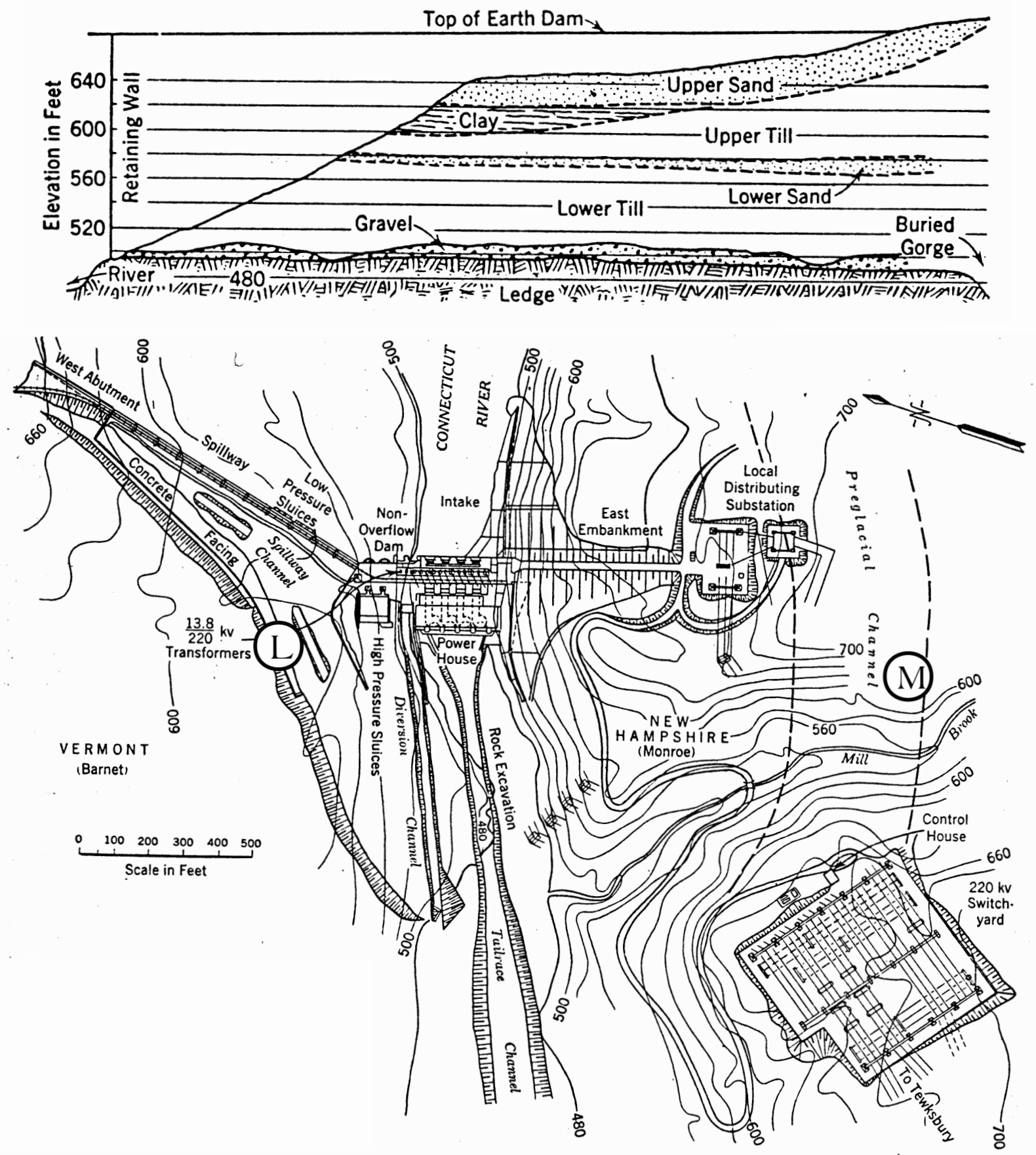

FIGURE 8. Map of Comerford Dam site and geologic section along east embankment of dam. L: approximate former location of varved clay exposure described by Lougee (1935). M: location of Mill Brook section. Adapted from Figures 2 and 3 in Crosby (1934a). Copyright (c) 1934 by the American Society of Civil Engineers. Reprinted with permission of the publisher.

Stratigraphy. Figure 10 shows a representative log of the Mill Brook section. The assemblage of silty-sandy diamicts and interbedded waterlaid sediments comprising Units 2-7 is the probable stratigraphic equivalent of Crosby's "upper till". Crosby's deformed "lower sand" is not apparent here, though
Carte du site du barrage de Comeford et coupe géologique du long de la digue orientale du barrage. $L$ : site de l'affleurement d'argile varvée décrite par Lougee (1935). M : site de la coupe de Mill Brook. Adapté à partir des figures 2 et 3 de Crosby (1934a). Droits de reproduction (c) 1934, à l'American Society of Civil Engineers. Carte reproduite avec la permission des éditeurs.

his cross section suggests it would be at the level of Unit 2 or 3 in Figure 10. Both Crosby's overlying "clay" unit and the laminated silt at the top of the Mill Brook section (Unit 8) were deposited in a lake, which we presume was Lake Hitchcock or a lower successor to this water body. 


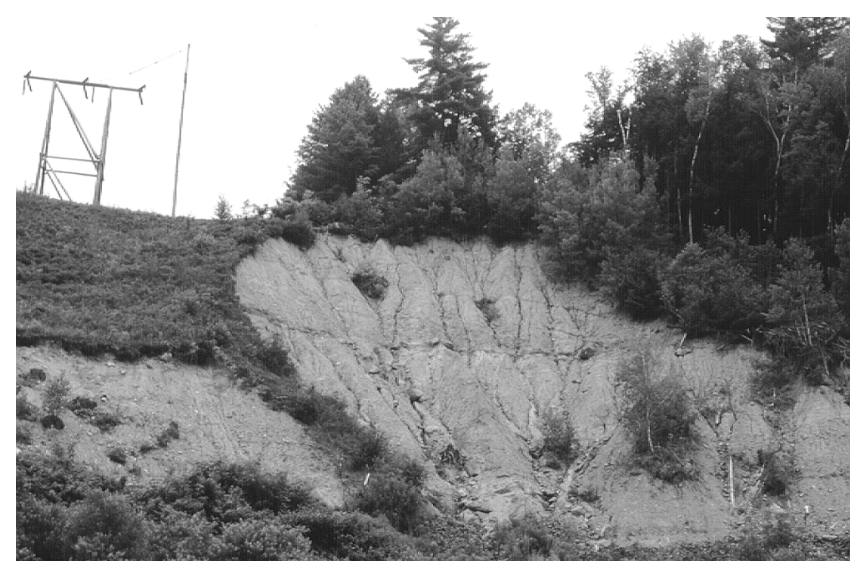

FIGURE 9. Mill Brook section near Comerford Dam. Gravel lag (Unit 5) can be seen midway up the face. View to east-northeast.

Coupe de Mill Brook près du barrage de Comeford. Résidu de déflation (unité 5) à mi-pente. Vue de l'est vers le nord-est.

There is a small exposure of very compact, silty, stony, gray lodgement till (Unit 1) in the lower left corner of the Mill Brook section, and the same dense till appears in another exposure farther down the brook. This is probably the "lower till" reported by Crosby (1934b). He attributed it to the most recent glaciation, but it might be the pre-Late Wisconsinan till that occurs widely as a lodgement facies across central and southern New England. The latter till exists in northern New Hampshire, where it has been called the Nash Stream Till (Koteff and Pessl, 1985). Fowler (this volume) has inferred the presence of the same older till in the Peabody River sections near Gorham. If a weathering profile formerly existed in Unit 1, it has been eroded away by younger glaciation.

A prominent boulder horizon (part of Unit 5) extends across the Mill Brook section. Boyce et al. (1995) noted similar boulder concentrations along erosion surfaces in till near Toronto, Ontario. They attributed these features to erosion and winnowing by subglacial meltwater. However, the boulders at the Canadian site have faceted and striated upper surfaces. The upper surfaces of the boulders in Unit 5 do not show evidence of glacial erosion, but appear more waterworn than the undersides. Unit 5 is believed to be a lag produced by meltwater beneath or in front of the glacier winnowing the underlying till.

There is no other apparent hiatus in the Mill Brook section. The thick pile of glacial diamicts and waterlaid sediments suggests prolonged deposition near the ice margin without major breaks. Units 2-4 and 6-7 represent two successive transitions
FIGURE 10. Stratigraphic log of Mill Brook section. Patterns within each unit schematically represent the range of sediment textures.

Stratigraphie établie à partir de la coupe de Mill Brook. Les différents motifs à l'intérieur des unités imitent la texture des sédiments.

\section{Depth \\ (m)}

UNIT

.

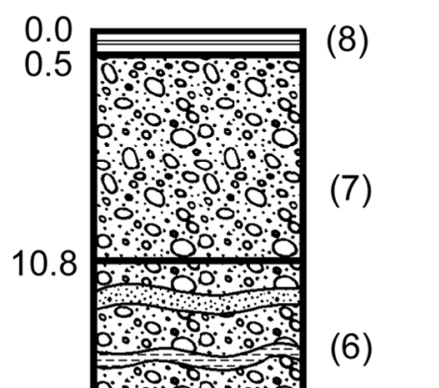

19.5

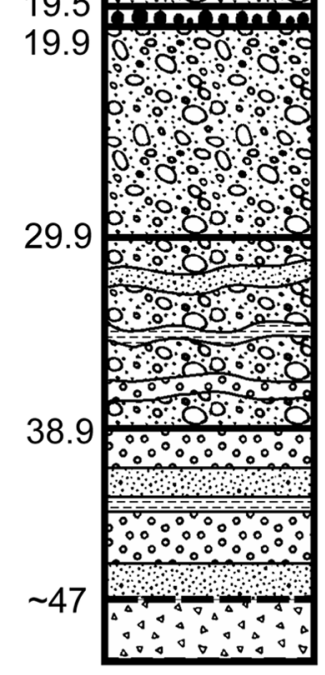

NNW
Laminated silt; olive-gray; oxidized. [lacustrine sediment]

Silty-sandy diamict; gray to olive-gray, depending on texture and oxidation state; generally massive and moderately compact, with angular pebbles-cobbles (a few faceted/striated and many rotten); conains silt-sand lenses, which are locally deformed. [till]

Silty-sandy diamicts interbedded with sand, gravel, and silt; unit shows much deformation.

Cobble-boulder lag, overlain by interbedded silt and sand showing folding and shearing.

Silty-sandy diamict; dark gray; massive, moderately compact, and stony; many stones are well rounded. [till]

Interbedded diamicts, sand, silt, and silty-sandy gravel; well rounded stones are common, even in the diamicts; deformation present in silt-sand beds.

Interbedded gravel, sand, and silt; bedding subhorizontal; gravel is massive and poorly sorted; clasts angular to well rounded; base of unit concealed by slump, but contact with Unit 1 inferred from nearby contact in same section.

Silty diamict; gray (non-oxidized); stony and very compact; this is the lower till of Crosby $(1934 \mathrm{a}, \mathrm{b})$. 
from ice-proximal environments (diamicts interpreted as flowtills, interbedded with meltwater deposits) to ice-marginal or subglacial till deposition. Recumbent folds and shear planes in Units 5 and 6 imply overriding by south-flowing ice, probably when the till of Unit 7 was deposited. Well-rounded stones in the diamict facies of Units 3 and 4 suggest that fluvial gravel was incorporated into the ice during the glacial advance recorded in the lower part of the section.

Provenance. Table II shows stone counts from the tills of Units 1, 4, and 7 in the Mill Brook section. Unit 1 (Crosby's "lower till") shows less variety than either of the higher tills. Tough diorite/metadiorite and a distinctive green-and-white pegmatitic gabbro total $56 \%$ of this unit. These rock types came from the Comerford intrusive suite (Rankin, 1994, 1995), which crops out at the dam site and to the north and north-northeast. The Comerford suite includes the Moulton diorite and associated dike swarms mapped by Eric and Dennis (1958) and Hall (1959). The dominance of these rock types is consistent with Unit 1 being a lodgement till and thus incorporating much of the underlying bedrock. Twenty percent of the clasts in Unit 1 are gray-to-black phyllite and schist. These pelitic rocks, together with associated quartzites $(7 \%)$, probably came from the Gile Mountain Formation and associated Meetinghouse Slate, which occur extensively north and north-northeast of Comerford Dam (Eric and Dennis, 1958; Hall, 1959; Rankin, 1994).

In the second stone count, from the upper part of Unit 4, quartzite is twice as abundant (15\%) and phyllite/schist increases slightly, but Comerford suite lithologies (gabbro

TABLE II

Stone counts from Mill Brook section, near Comerford Dam, Monroe, NH

\begin{tabular}{lccc}
\hline Rock Type & Unit 1 & Unit 4 & Unit 7 \\
\hline Gabbro / pegmatitic gabbro & 40 & 10 & 7 \\
(Comerford intrusive suite) & - & 1 & - \\
Basalt & & & \\
Diorite / metadiorite & 16 & 7 & 6 \\
(Comerford intrusive suite) & - & 13 & - \\
Granite (pink) & 8 & 9 & - \\
Granite (white) & - & - & 2 \\
Granite (undifferentiated) & - & 4 & - \\
Rhyolite & & & \\
Phyllite / schist (gray to black) & 20 & 26 & 53 \\
(Gile Mtn. / Meetinghouse) & - & 5 & 1 \\
Schist (brown) & - & - & 2 \\
Biotite gneiss & & & \\
Quartzite & 7 & 15 & 13 \\
(Gile Mtn. Fm. / Meetinghouse Slate) & 2 & 1 & 6 \\
Amphibolite & 6 & 2 & 6 \\
Granofels & 1 & 5 & 4 \\
Vein quartz & - & 2 & - \\
Other & 100 & 100 & 100 \\
Total & & & \\
\hline &
\end{tabular}

and diorite) drop sharply to $17 \%$. Pink granitic rocks of unknown origin are prominent in this unit. White two-mica granites may have come from the "two-mica granitoid dikes" or "two-mica tonalite" that crop out within several kilometers north of here (Rankin, 1994). Many of the stones in Unit 4 $(40 \%)$ are well rounded, some with fresh surfaces from glacial breakage. Few clasts are faceted or striated. Thus, we infer that the ice that deposited this till incorporated much streamlaid gravel (possibly from Units 2 and 3 ) and carried it only a short distance.

In the Unit 7 till, phyllite/schist jumps markedly to $53 \%$, quartzite remains moderately abundant, and rocks of the Comerford suite are less common than in Units 1 and 4. Thus, the data in Table II collectively indicate that younger tills in the Mill Brook section show a progressive decrease in clasts of the local Comerford intrusive suite, and an increase in pelitic and quartzose metasediments attributed to the Gile Mountain Formation and Meetinghouse slate.

Interpretation. Although the stone counts suggest a shift in source area with time, the abundance of Comerford suite and Gile Mountain/Meetinghouse lithologies in all three samples indicates local sources to the north for the tills at Mill Brook. The striae and till provenance both show that glacial ice consistently flowed southward across the Comerford Dam area, not down the Connecticut Valley from Littleton as proposed by Crosby (1934b). If ice had flowed west along the valley, the Mill Brook tills should contain many rocks from the Albee Formation and Ammonoosuc Volcanics in areas mapped by Eric and Dennis (1958) and Rankin (1994).

We also doubt Crosby's hypothesis that the deposits at Comerford Dam indicate a late-glacial ice tongue advancing (or readvancing) into a lake. The Mill Brook section (Fig. 10) records two advances of the ice margin, but the sediments do not appear to have been deposited in standing water. Although the sand and gravel facies might have been deposited as lacustrine fans at the ice margin, the associated diamicts lack the characteristics of subaquatic flowtills described by Evenson et al. (1977). Unequivocal lacustrine muds occur only at the top of the section.

It remains uncertain whether part of the Mill Brook section correlates with the Bethlehem Moraine complex. Westward extrapolation of ice-margin positions recorded by moraines in Littleton suggests that the readvance which deposited these moraines should have terminated near Comerford Dam. Assuming the readvance reached this locality, at least two scenarios are possible. If Crosby's lower till (Unit 1) is pre-Late Wisconsinan, the remainder of the Mill Brook section represents Late Wisconsinan glaciation. In that case, only the upper glacial-advance deposits (units 5-8) would likely correlate with the Bethlehem Moraine complex. Alternatively, the lower till represents the Late Wisconsinan glacial maximum, and all or most of Units 2-7 were deposited from a late-glacial oscillating ice margin contemporaneous with the Bethlehem Moraine complex. 


\section{BEECH HILL MORAINES}

We discovered a group of end moraines just north of Beech Hill in the town of Carroll (northeast part of Fig. 3). These moraines are located about $7 \mathrm{~km}$ east of the Bethlehem Moraine complex, at elevations of 396-427 m (1300-1400 ft). They comprise at least six till ridges that are 4-12 $\mathrm{m}$ high, up to $700 \mathrm{~m}$ long, and trend ENE-WSW. An exposure in one ridge (Fig. 11) shows light olive-gray till that is loose, sandy, stony, and non-stratified. Large boulders of white granite (up to $3 \mathrm{~m}$ wide) are very abundant on the surfaces of the moraines.

Meltwater channels occur on the distal sides of several of the Beech Hill moraines. The largest of these channels lies along the southern margin of the moraine cluster. It is a prominent topographic feature in which an elongate pond is now located. The channels developed sequentially in the swales between moraine ridges and thus are parallel to the moraines. Erosion of the channels by meltwater streams has locally accentuated the apparent heights of adjacent moraines, but does not account for their total relief. Meltwater flowed southwest along the ice margin as it retreated from Beech Hill and drained through the 387-m gap between the northwest corner of Beech Hill and Pine Knob (Fig. 3).

The Beech Hill moraines can be correlated with the younger parts of the Bethlehem Moraine complex. Figure 3 shows a proposed ice-margin position linking these two areas. The inferred ice margin also would have dammed a small lake (glacial Lake Carroll) in the north-draining valley east of the Beech Hill moraines. This lake was originally proposed by Lougee (n.d.). Water escaping westward from Lake Carroll may have helped cut the channels between the moraines.

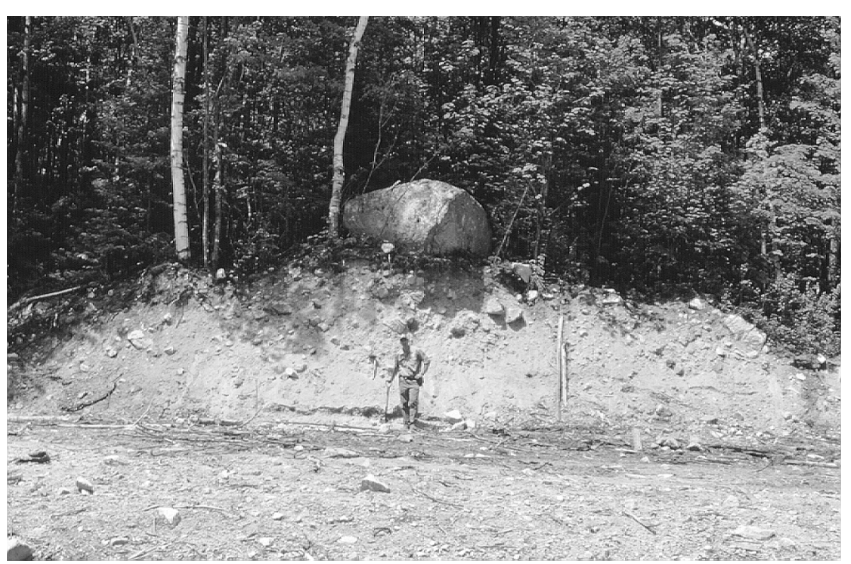

FIGURE 11. Excavation showing cross section through one of the Beech Hill moraines in Carroll. View to west.

Excavation qui a dégagé une coupe dans une des moraines de Beech Hill à Carroll (vue vers l'ouest).

\section{ISRAEL RIVER VALLEY}

Other deposits that probably correlate with the Bethlehem and Beech Hill moraines occur to the northeast, in the upper part of the Israel River valley between Jefferson and Randolph (Figs. 1, 12). We found several prominent boulder-covered end moraines on the south side of the valley, approximately $1.2-1.6 \mathrm{~km}$ west-southwest of the IsraelAndroscoggin drainage divide at Bowman. These moraines are located along the power line that follows the valley side. They trend northeast and are up to $12 \mathrm{~m}$ high.

The ice margin that deposited the above moraines also dammed the earliest phase (Bowman stage) of glacial Lake Israel. An ice-contact delta on the north side of the Israel Valley grades to a 457-m bedrock spillway at the Bowman

FIGURE 12. Map showing upper Israel River valley and sites discussed in text. B: Bowman spillway for glacial Lake Israel. C: Corrigan Pit. P: Pond of Safety. Short arrows indicate sets of meltwater channels; heavy black lines near Bowman are moraines.

Carte montrant la vallée supérieure de l'Israel River ainsi que certains sites ont on parle dans le texte. $B$ : déversoir Bowman pour le Lac glaciaire Israel; $C$ : ballastière de Corrigan ; $P$ : Pond of Safety. Les petites flèches montrent un ensemble de chenaux de fonte ; les traits noirs près de Bowman représentent des moraines.

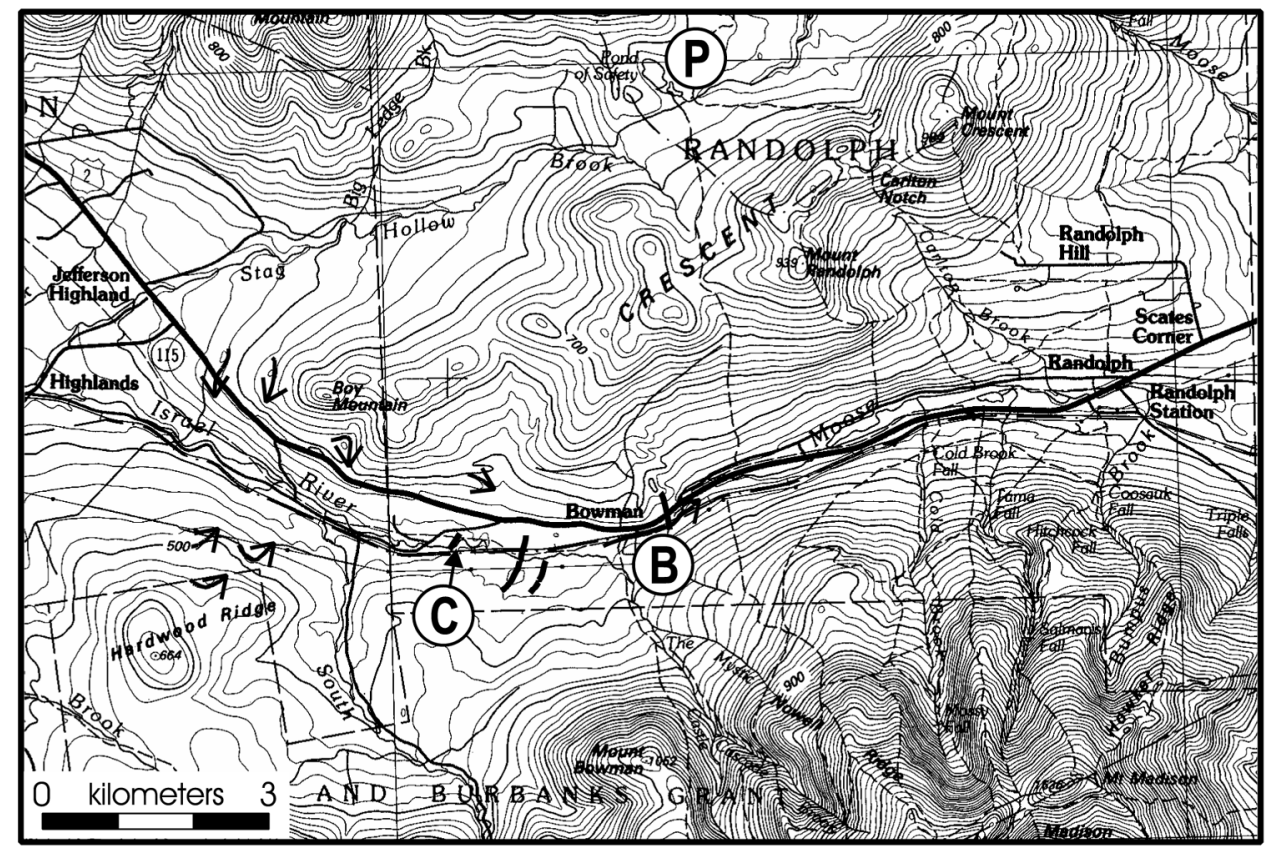


divide (Fig. 12). Descending flights of lateral meltwater channels were carved into till on both sides of the Israel Valley at about the same time as the moraines and deltas were deposited. These channels are located on Boy Mountain on the north side of the valley, and the northern slope of Hardwood Ridge along the south side (Fig. 12 and map by Goldthwait and Mickelson, 1982). They indicate thinning and westward recession of a valley ice tongue. The Boy Mountain channels were described in detail by Lougee (n.d.). Other morainic till ridges and hummocks occur downvalley to the west, near Jefferson village, and subaqueous fans were deposited in deeper lake waters of the Bowman and later stages of Lake Israel.

The Corrigan Pit reveals further details concerning deglaciation of the Israel River valley. This pit is located on the north side of the river, $0.8 \mathrm{~km}$ east of the Jefferson-Randolph town line (Fig. 12). It shows glaciolacustrine sand, with foreset beds prograding east, overlain by ice-proximal gravel. The gravel is overlain by $6 \mathrm{~m}$ of stony glacial till forming a moraine ridge. Thrust faults in the Corrigan Pit indicate ice shove from the west (Thompson et al., 1996). A shallow excavation on the north side of the pit area reveals lacustrine silt and sand that is very compact and complexly deformed. Across Valley Road to the northwest, another small pit shows about $3 \mathrm{~m}$ of deformed fine-grained glaciolacustrine sediments with dropstones and thin beds of silty-pebbly diamict.

The deposits in the vicinity of the Corrigan Pit record the advance of an ice margin into glacial Lake Israel. We interpret the lacustrine sands as subaqueous fan deposits, which in the Corrigan Pit were blanketed by fan gravel, then by gravelly diamict flows, and finally by till as ice approached the site. The morainic topography suggests that these deposits resulted from a readvance during the recession of the Late Wisconsinan ice sheet. The overconsolidated and deformed lake sediments in the small pits near Valley Road further indicate readvance into the lake.

By analogy with Alaskan glaciers, Goldthwait and Mickelson (1982) interpreted glacial features in the Jefferson-Randolph area as demonstrating early stagnation of the Late Wisconsinan ice sheet, with development of a ragged ice margin as the glacier thinned over high-relief terrain. However, these authors did not differentiate the "ice-contact deposits" that they mapped in the Israel Valley. We found those deposits to include end moraines, ice-contact deltas, and lacustrine fans. Although the glacier margin became irregular and lobate as the ice sheet receded, evidence in and near the Corrigan Pit indicates that the ice tongue in the Israel Valley remained active and experienced stillstands or readvances during its overall recession. Moreover, the positions of moraines and other ice-marginal features in the upper Israel Valley suggest they formed at about the same time as the Bethlehem Moraine complex and the Beech Hill moraines. When the glacier margin impinged against the north side of Beech Hill, it probably continued eastward around the north side of Cherry Mountain and up the Israel Valley, damming the Bowman Stage of glacial Lake Israel.

\section{GLACIAL LAKE AMMONOOSUC}

Warren Upham's work with the Hitchcock survey led him to propose that a lake had existed in the Fabyan area in the upper part of the Ammonoosuc River valley (Upham, 1878). Goldthwait (1916) named this water body "Lake Ammonoosuc". It resulted from damming of the west-draining valley by a tongue of Late Wisconsinan ice receding from the Bethlehem area. As the ice margin withdrew, successively lower spillways for the lake were uncovered and the lake level fell.

Goldthwait identified two levels of glacial Lake Ammonoosuc: a higher level into which the "pitted outwash plain" and other ice-contact deposits at Carroll and Twin Mountain were built, followed by a lower level into which the Bethlehem Moraine was deposited. He noted that a glacial lake in the Ammonoosuc Valley could only have been dammed by the "Canadian ice-sheet" retreating to the northwest, and not by the margin of a local ice cap withdrawing into the mountains to the south (Goldthwait, 1916). Lougee (n.d.) realized that an earlier and higher stage of Lake Ammonoosuc (his "Crawford Stage") drained east through Crawford Notch at an elevation of approximately $573 \mathrm{~m}(1880 \mathrm{ft})$. This was the same route followed by a subglacial tunnel drainage which formed the esker in the upper Ammonoosuc Valley (Goldthwait and Mickelson, 1982).

We have named the post-Crawford stages of Lake Ammonoosuc, whose spillways are shown in Figure 3. However, it was Lougee's undated manuscript (ca. 1930) that first identified some of these lake levels and their outlets. After the Crawford Stage, glacial Lake Ammonoosuc drained southwestward through five progressively lower spillways (G1-G5 in Fig. 3) into the Gale River valley. The spillway for the Gale River 2 Stage is a prominent channel that can be seen along U. S. Route 3 west of Twin Mountain. Later spillways north of Bethlehem village drained the Bethlehem and Wing Road Stages of Lake Ammonoosuc into Indian Brook and later directly into the Ammonoosuc River.

The Gale River and younger stages of the lake generally were not deep, so the ice margin probably was grounded on the lake floor. The widest and deepest stage may have been Gale River 2. Well CFW 53, just west of Twin Mountain (Fig. 1), encountered a contact between thick glaciolacustrine clay and the underlying till at an elevation of $401 \mathrm{~m}$ (Flanagan, 1996). Comparison with the nearby G2 spillway elevation of $445 \mathrm{~m}$ (Fig. 3) indicates a water depth of at least $44 \mathrm{~m}$.

Figure 3 shows proposed recessional positions of the Late Wisconsinan ice margin that were contemporaneous with the Gale River and later stages of Lake Ammonoosuc. We infer these ice margins from the orientation of segments of the Bethlehem Moraine complex, together with ice blockages of the valley that would have been required to hold the lake at elevations corresponding to the known deltas and spillways.

The clearest example of how the ice margins can be reconstructed is seen by comparing elevations of delta tops and other meltwater-graded surfaces in the Carroll-Twin Mountain area with the corresponding lake outlets to the southwest (Fig. 3). When the Carroll delta ("C") was deposited into the 
Gale River 2 stage of Lake Ammonoosuc ( $445 \mathrm{~m}$ ), the ice margin must have wrapped around Beech Hill and blocked the lower part of the valley, forcing lake drainage through the G2 spillway (at the same elevation as the water plane indicated by the Carroll delta). Recession of the ice margin then opened the G3 spillway (Fig. 3), and the lake dropped to $435 \mathrm{~m}$. At this time a deep channel was cut into the Carroll delta (Thompson et al., 1996) and a lower delta plain was graded to this elevation at Twin Mountain.

The agreement between elevations of Lake Ammonoosuc deltas and terraces in Twin Mountain, and the matching spillways of the Gale River 2-4 Stages, suggests that the receding glacier margin was a tight dam for the lowering lake. Lougee's (1940) diagram (Fig. 13) shows the ice margin lying against the northwest flanks of Beech Hill and Cherry Mountain when the Carroll delta was built. His model was the basis for the lake history proposed here. The only significant discrepancy is that we see no evidence for Lougee's postulated meltwater channels extending along the entire west side of Cherry Mountain. Sediment was conveyed to the Carroll delta via englacial tunnel drainage and short hillside channels that feed into the northeast corner of this delta (Thompson et al., 1996).
During the evolution of Lake Ammonoosuc, water entered the lake not only from the melting glacier but also from the early Ammonoosuc River and smaller streams draining the surrounding mountains, as shown by Lougee (Fig. 13). Much of the sediment deposited in Lake Ammonoosuc probably came from these nonglacial sources. The mouth of the river shifted westward as the lake level dropped, and the lake ultimately disappeared when the ice margin receded from the Alderbrook area in northernmost Bethlehem (Fig. 3). At this time, the upper reach of the Ammonoosuc River joined with the lower part of the river that continues southwest from Littleton. Since the drainage of Lake Ammonoosuc, flood plain and alluvial fan deposits have accumulated on the old lake floor. These deposits are very thick in places, such as the Little River valley west of Twin Mountain village (Flanagan, 1996).

\section{DISCUSSION}

\section{BETHLEHEM MORAINE COMPLEX AND THE LITTLETON- BETHLEHEM READVANCE}

Previous work and our new observations have shown that the subparallel till ridges in the Ammonoosuc Valley near Bethlehem and Littleton are end moraines, especially the

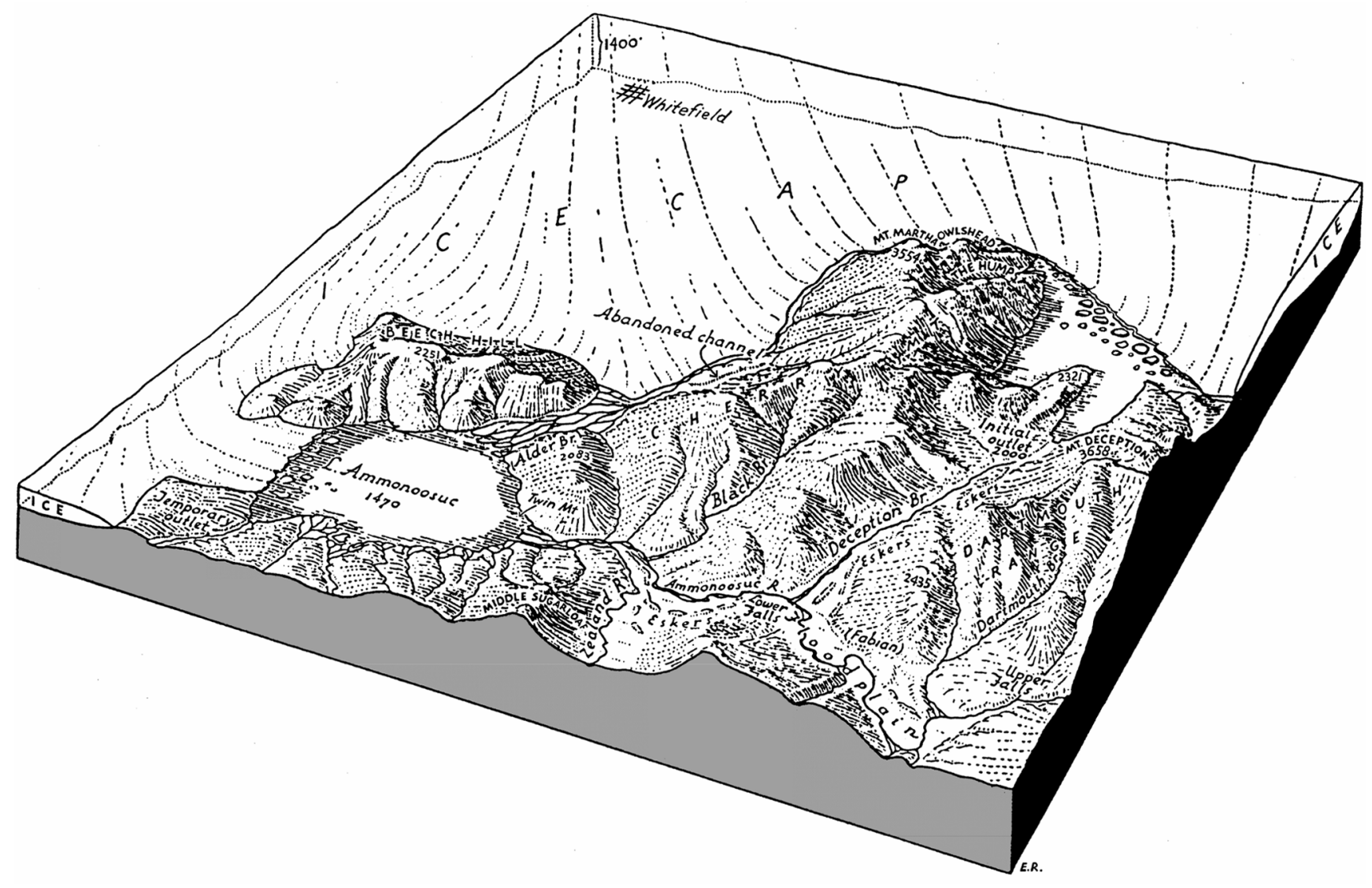

FIGURE 13. Diagram from R. J. Lougee (1940), showing location of ice margin when the Carroll delta was deposited into Gale River 2 Stage of glacial Lake Ammonoosuc.
Bloc diagramme tiré de R.J. Lougee (1940), montrant la localisation de la marge glaciaire au moment de la formation du delta de Carroll lors du stade de Gale River 2 du Lac glaciaire Ammonoosuc. 
high, robust ridges like those south of Littleton (Fig. 4). Together with the deposits and corresponding spillways of glacial Lake Ammonoosuc, these moraines indicate progressive northward retreat of a coherent ice margin during Late Wisconsinan deglaciation.

The great volume of sediment in the Bethlehem Moraine complex implies active ice supplying debris to the Ammonoosuc River basin when these deposits formed. Following a readvance of the ice margin to the southern limit of the complex, retreat through the positions shown in Figure 3 was interrupted by brief stillstands or forward pulses during which the moraines were deposited. We suggest that the readvance and closely related glacial oscillations be called the "Littleton-Bethlehem Readvance". This name incorporates both the Littleton-Bethlehem area, with its continuous and well-known morainic belt, and Lougee's (1935) "ice readvance at Littleton". Lougee coined the latter term for the event that deposited the Bethlehem Moraine complex, which he equated with the readvance documented in the varve stratigraphy at Comerford Dam (Ridge et al., this volume).

We correlate the Bethlehem Moraine complex with other ice-marginal features extending along the northwest flank of the White Mountains from Littleton to the headwaters of the Israel River north of the Presidential Range. The LittletonBethlehem Readvance is inferred to have deposited the moraines north of Beech Hill and in the upper Israel Valley. Hitchcock (1897) and Crosby (1934b) suggested a more extensive correlation with deposits farther east, at Gorham. This is improbable because ice-marginal deposits in the Israel Valley postdate the deglaciation of the Gorham area. To the west of Bethlehem and Littleton, the readvance is probably evident in the till and varve stratigraphy near Comerford Dam. Thus, the known lateral extent of the LittletonBethlehem Readvance ranges from Bowman to the Connecticut Valley as shown in Figure 1, a straight-line distance of approximately $55 \mathrm{~km}$.

The Bethlehem Moraine complex is just south of a NE-trending chain of hills in the Dalton Range (Fig. 1), which reach elevations of $500-650 \mathrm{~m}$. The profile of the ice margin must have been steep enough for the ice sheet to override these hills and deposit the moraines in the Ammonoosuc Valley. An average ice-surface gradient of at least $40 \mathrm{~m} / \mathrm{km}$ was required to clear the hills north of Littleton and deposit the youngest of the large end moraines south of Route 302 (Fig. 4). North of Bethlehem, the marginal slope must have been at least $50 \mathrm{~m} / \mathrm{km}$ between the Dalton Range and the moraines just south of the Ammonoosuc River.

Recent exposures in pits belonging to Chick's Sand and Gravel in Dalton (between the Ammonoosuc River and Dalton Range) provide clues to how far the ice margin retreated just prior to the Littleton-Bethlehem Readvance. A gravel outwash fan high on the south flank of Dalton Mountain overlies unweathered ablation till that appears identical to Late Wisconsinan surface till throughout the region. This gravel presumably was deposited during the initial retreat of the ice sheet. It is very compact, locally deformed, and overlain by large boulders, so we infer that it was overriden by ice during the Littleton-Bethlehem Readvance. Final recession of the glacier margin to the northwest side of the range was accompanied by a great discharge of meltwater through a gap on Dalton Mountain, carving meltwater channels up to $30 \mathrm{~m}$ deep. If this reconstruction is correct, the ice margin must have readvanced at least the $12 \mathrm{~km}$ from the Dalton Range to the southern limit of the Bethlehem Moraine complex.

\section{DEGLACIATION CHRONOLOGY OF THE WHITE MOUNTAINS}

Davis and Jacobson (1985), Dyke and Prest (1987), and Occhietti (1989) have proposed regional deglaciation chronologies for New England and adjacent Canada. These authors synthesized radiocarbon dates that provide minimum limits on the time of ice retreat, and they prepared paleogeographic maps showing the inferred extent of glacial ice at various times following the Late Wisconsinan glacial maximum. Their reconstructions show northern New Hampshire being deglaciated between 14,000 and $13,000{ }^{14} \mathrm{C}$ yr BP, followed by recession of the Laurentide Ice Sheet into southeastern Québec and marine transgression in the St. Lawrence Lowland (Québec City area) shortly after 12,000 BP. (All dates subsequently presented here are in radiocarbon years.) The New England chronology is based on dates from terrestrial and a few marine sites (Davis and Jacobson, 1985), while the invasion of the Champlain Sea in adjacent Québec is constrained by radiocarbon dates on marine shells from near the upper limit of submergence (Parent and Occhietti, 1988).

Figure 14 and Table III show AMS radiocarbon dates from ponds in the White Mountains and adjacent areas, mostly from the lower or basal portions of sediment cores. These dates limit the time of deglaciation of each site. Pond of Safety in the mountains just north of the Presidential Range in New Hampshire (Site 5; Fig. 12) is favorably located to provide a minimum age for deposition of the Androscoggin Moraine to the east (Thompson and Fowler, 1989) and a maximum age for the Bethlehem Moraine complex to the west. The basal date from Pond of Safety is $12,450 \pm 60$ BP (OS-7125; Thompson et al., 1996). This date is compatible with other limiting dates from northern New Hampshire (Fig. 14), as well as the date of 12,250 BP (OS-7119) from Surplus Pond in western Maine (Site 6). The cores from both of these ponds show sedimentological evidence of climatic cooling that probably occurred in Younger Dryas time (Thompson et al., 1996).

The radiocarbon dates in Figure 14 are generally younger to the north, in the direction of glacial retreat. If these dates closely approximate the time of deglaciation, they show that the Late Wisconsinan ice margin receded from the White Mountains to southeastern Québec between 13,000 and $11,000{ }^{14} \mathrm{C}$ years ago. Thompson et al. (1997) estimated an average retreat rate of $70 \mathrm{~m} / \mathrm{yr}$ between Cushman Pond (Site 1) in western Maine and the Frontier Moraine on the Québec border. 


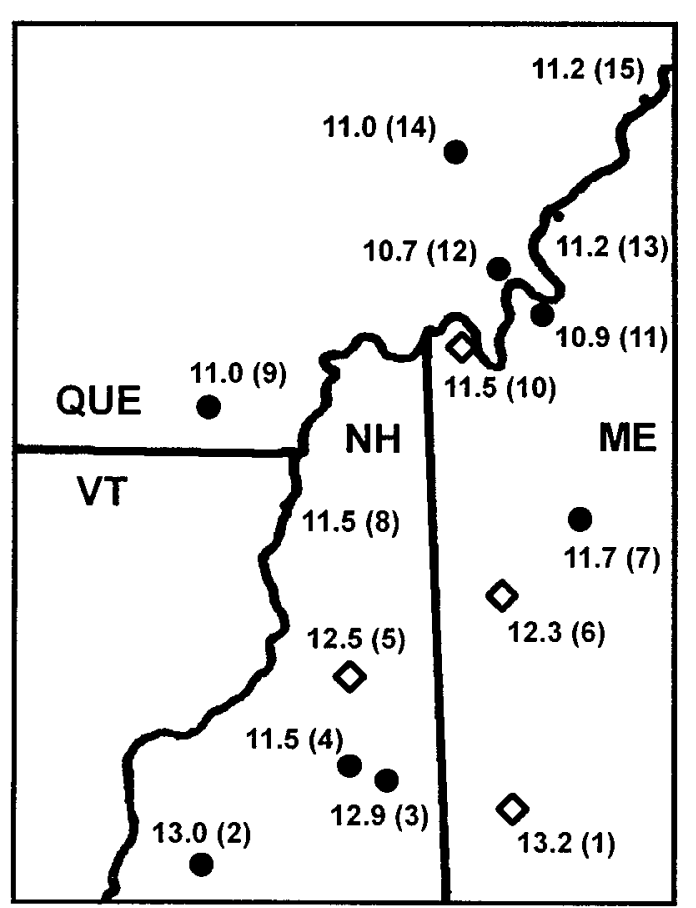

FIGURE 14. Map showing locations of ponds in the White Mountains and surrounding areas from which radiocarbon dates have been obtained from sediment cores. Only the oldest dates are shown, which are believed to approximate the time of deglaciation at each site. Numbers are ages in thousands of radiocarbon years BP, with site numbers (in parentheses) keyed to Table III. Diamonds indicate ponds cored by the authors.

Carte montrant la localisation des lacs dans les White Mountains et les environs d'où ont été obtenues des dates au radiocarbone à partir des carottes de sédiments. N'apparaissent que les dates les plus anciennes, qui, croit-on, donnent la date approximative de la déglaciation au site même. Les chiffres sont en milliers d'années BP et sont suivis du numéro du site entre parenthèses (tabl. III). Les losanges localisent les lacs sondés par les auteurs

The date from Pond of Safety suggests that the northwestern White Mountains were deglaciated, and the Bethlehem Moraine complex and correlatives were deposited, soon after $12,500 \mathrm{BP}$. This is about the time that Ridge and Larsen (1990) inferred for initial drainage of glacial Lake Hitchcock in the Connecticut Valley (12,400-12,300 BP). No high-stand Lake Hitchcock deltas have been found as far up the Ammonoosuc Valley as Littleton (C. Koteff, pers. comm.), so the lake level may indeed have started to fall when the ice margin stood in this area.

For the northwestern White Mountains, the deglaciation chronology suggested by Figure 14 is younger than the $14,000-13,000$ BP interval proposed by Davis and Jacobson (1985) and Occhietti (1989). It is closer to estimates based on the Connecticut Valley varve record. This record is tied to radiocarbon-dated Lake Hitchcock varves at the Canoe Brook site in southeastern Vermont (Ridge and Larsen, 1990). Ridge et al. (1996 and this volume) correlated varve exposures near Comerford Dam with the varve sequence of Antevs (1922) and regional paleomagnetic declinations from varve sites. These authors concluded that the readvance proposed by earlier workers at the dam site (and by extrapolation, deposition of the Bethlehem moraines as well) occurred at about 12,000 BP.

Figure 14 shows that the Boundary Mountains on the Québec border may have been deglaciated as recently as 11,500 to $11,000 \mathrm{BP}$, but marine shell dates indicate that the Champlain Sea transgression had already occurred by this time in the St. Lawrence Lowland to the north (Parent and Occhietti, 1988). If both of these conditions are true, the Frontier Moraine and other moraines to the west (Sherbrooke area) would have been deposited by an Appalachian ice mass that was separated from the Laurentide Ice Sheet by the marine incursion. It is well known that a residual ice cap developed over northern Maine and adjacent Québec, but this ice cap did not extend much farther southwest than Thetford Mines (Parent and Occhietti, 1988). In the area from the Frontier Moraine west to Sherbrooke, the lobation of moraines and meltwater flow directions (including eskers) consistently record the northwestward recession of the Laurentide ice margin (Gadd et al., 1972; Shilts, 1981; Dyke and Prest, 1987; Parent and Occhietti, 1988). Similarly, there is no indication that a late-glacial local ice mass formed over northern New Hampshire or adjacent parts of Maine and Vermont.

The above problem raises the question of whether the Québec marine shell dates are too old or the deglaciation dates inferred from pond cores are too young. A correction for the marine reservoir effect would make the marine shell dates younger, and the terrestrial dates may lag behind the time of deglaciation. Moreover, Rodrigues (1992) claimed that the marine-limit dates are too old, and that dates from deeper parts of the Champlain Sea indicate that marine transgression in the central St. Lawrence lowland began between 11,600 and $11,400 \mathrm{BP}$.

Considering the basal pond dates (Fig. 14) and Connecticut Valley varve chronology (Ridge et al., this volume), we believe the Littleton-Bethlehem Readvance occurred at approximately $12,000 \mathrm{BP}(\sim 14,000 \mathrm{cal} \mathrm{yr})$. The cause of the readvance is uncertain, but low terrain in the Connecticut River basin north of Littleton would have favored late-glacial ice flow. Buttressing of the ice against northwest-facing slopes, and the existence of ice-marginal lakes, may have promoted deposition of moraines along the ice front between Littleton and Randolph. However, there is no topographic factor that would have triggered the widespread glacial readvance in this region, so climatic deterioration probably was responsible.

Thompson (1998) suggested that the Littleton-Bethlehem Readvance occurred during the Older Dryas Chronozone. This cold interval began 12,200-12,000 BP and lasted only about 200 years (Donner, 1995; Wohlfarth, 1996). The GISP2 ice core from Greenland likewise indicates a brief cold period around $12,000 \mathrm{BP}$ that is equated with the Older Dryas (Stuiver et al., 1995). Björck et al. (1998) recommended that the GRIP Greenland ice core should be the standard for an isotopic record of late-glacial climate change in the North Atlantic region. These authors designated the cold period at 12,000 BP as episode Gl-1d within "Greenland Interstadial 1" in the GRIP core. Regardless of which climate terminology is 
TABLE III

Radiocarbon dates limiting time of deglaciation in the White Mountains

\begin{tabular}{lccl}
\hline Site & Lab No. & Age $\left({ }^{14} \mathrm{C}\right.$ yr BP) & Reference \\
\hline 1. Cushman Pond & OS-7122 & $13,150 \pm 50$ & Thompson et al. (1996) \\
2. Deer Lake Bog & QL-1133 & $13,000 \pm 400$ & Davis et al. (1980) \\
3. Lost Pond & QL-985 & $12,870 \pm 370$ & Davis et al. (1980) \\
4. Lake of the Clouds & I-10684 & $11,530 \pm 420$ & Spear (1989) \\
5. Pond of Safety & OS-7125 & $12,450 \pm 60$ & Thompson et al. (1996) \\
6. Surplus Pond & OS-7119 & $12,250 \pm 55$ & Thompson et al. (1996) \\
7. Spencer Pond & AA-9506 & $11,665 \pm 85$ & C. Dorion (unpub. data) \\
8. Columbia Bridge & WIS-961 & $11,540 \pm 110$ & Miller and Thompson (1979) \\
9. Barnston Lake & GSC-420 & $11,020 \pm 330$ & McDonald (1968) \\
10. Lower Black Pond & OS-7123 & $11,500 \pm 50$ & Thompson et al. (1996) \\
11. Chain of Ponds & $?$ & $10,860 \pm 160$ & Borns and Calkin (1977) \\
12. Lac aux Araignees & GSC-1353 & $10,700 \pm 310$ & Shilts (1981) \\
13. Boundary Pond & GSC-1248 & $10,200 \pm 200$ & Shilts (1981) \\
14. Lac à la Truite & GSC-1289 & $11,000 \pm 240$ & Shilts (1981) \\
15. Lac Dufresne & GSC-1294 & $11,200 \pm 160$ & Shilts (1981) \\
\hline
\end{tabular}

preferred, the age of the cooling event traditionally called the Older Dryas agrees with the probable age of the LittletonBethlehem readvance. The ice sheet must have responded quickly in northern New Hampshire if deposition of the Bethlehem Moraine complex was limited to this brief interval.

\section{ACKNOWLEDGEMENTS}

The authors are grateful to the following persons and companies who granted permission to examine geological features on their properties: Jennifer Cartwright and Doug Gray, Bethlehem; Ken W. Corrigan, Inc., Randolph; Sean Dodge, Dodge Contracting, Littleton; Doug Ingerson, Jr., Chick's Sand and Gravel, Littleton; New Hampshire Department of Transportation; Tom Pancoast, Littleton; Twin Mountain Sand \& Gravel (of Tilcon-Arthur Whitcomb, Inc.), Carroll; and John Wedick, Jr., Wing Road Commons, Ltd., Bethlehem. Many other residents of Bethlehem and Littleton kindly assisted us in various ways.

We appreciate the assistance of John Poisson (Maine Geological Survey) in preparing the figures for this article. We also thank Dr. Eugene Boudette, State Geologist of New Hampshire, and the New Hampshire Water Well Board for supplying well logs and other data. Stewart Clark, Jr., Sarah Flanagan, and Carol Hildreth contributed greatly to discussions of the glacial history of the study area based on their aquifer studies for the U.S.G.S. Helpful suggestions in the field were also provided by Jon Boothroyd, Carl Koteff, and Jack Ridge; comments by David Mickelson and Richard Waitt greatly improved this paper. Peter Crane and Guy Gosselin assisted in locating reference materials at the Mount Washington Observatory's Resource Center in North Conway.

\section{REFERENCES}

Agassiz, L., 1870. On the former existence of local glaciers in the White Mountains. American Association for the Advancement of Science, Proceedings, 19: 161-167 (also in American Naturalist, 4: 550-558, 1870).
Antevs, E., 1922. The recession of the last ice sheet in New England. American Geographical Society, Research Series 11, 120 p. +6 pl.

Billings, M. P., 1935. Geology of the Littleton and Moosilauke Quadrangles, New Hampshire. State Planning and Development Commission, Concord, $51 \mathrm{p}$.

Björck, S., Walker, M. J. C., Cwynar, L. C., Johnsen, S., Knudsen, K., Lowe, J. J., Wohlfarth, B., and INTIMATE members, 1998. An event stratigraphy for the last termination in the North Atlantic region based on the Greenland ice-core record: a proposal by the INTIMATE group. Journal of Quaternary Science, 13(4): 283-292.

Borns, H. W., Jr. and Calkin, P. E., 1977. Quaternary glaciation, west-central Maine. Geological Society of America Bulletin, 88: 1773-1784.

Boyce, J. I., Eyles, N. and Pugin, A., 1995. Seismic reflection, borehole and outcrop geometry of Late Wisconsin tills at a proposed landfill near Toronto, Ontario. Canadian Journal of Earth Sciences, 32: 1331-1349.

Crosby, I. B., 1928. Geological report on the Fifteen Mile Falls Development for the New England Power Construction Company. Unpub. report, 99 p. (Mass. Inst. Tech. archives).

1929. Second supplement to the Geological report on the Fifteen Mile Falls Development for the New England Power Construction Company-the New Hampshire bluff at the lower dam: unpub. report, 23 p. (Mass. Inst. Tech. archives).

1934a. Geology of the Fifteen-Mile Falls development. Civil Engineering, 4(1): 21-24.

1934b. Extension of the Bethlehem, New Hampshire, moraine. Journal of Geology, 42: 411-421.

Davis, M. B., Spear, R. W. and Shane, L. C. K., 1980. Holocene climate of New England. Quaternary Research, 14: 240-250.

Davis, R. B. and Jacobson, G. L., Jr., 1985. Late-glacial and early Holocene landscapes in northern New England and adjacent areas of Canada. Quaternary Research, 23: 341-368.

Donner, J., 1995. The Quaternary history of Scandinavia. Cambridge University Press, Cambridge, $200 \mathrm{p}$.

Dyke, A. S. and Prest, V. K., 1987. Late Wisconsinan and Holocene retreat of the Laurentide Ice Sheet. Géographie physique et Quaternaire, 41(2): 237-263.

Eric, J. H. and Dennis, J. G., 1958. Geology of the Concord-Waterford area, Vermont. Vermont Geological Survey, Bulletin 11, $66 \mathrm{p}$.

Evenson, E. B., Dreimanis, A. and Newsome, J.W., 1977. Subaquatic flow tills: A new interpretation for the genesis of some laminated till deposits. Boreas, 6 : 115-133.

Flanagan, S. M., 1996. Geohydrology and water quality of stratified-drift aquifers in the middle Connecticut River basin, west-central New Hampshire. U. S. Geological Survey, Water-Resources Investigation Report 94-4181, 169 p. 
Gadd, N. R., McDonald, B. C. and Shilts, W. W., 1972. Deglaciation of southern Québec. Geological Survey of Canada, Paper 71-47, $19 \mathrm{p}$.

Gerath, R. F., 1978. Glacial features of the Milan, Berlin, and Shelburne map areas of northern New Hampshire. M. S. thesis, McGill University, 129 p.

Gerath, R. F., Fowler, B. K. and Haselton, G. M., 1985. The deglaciation of the northern White Mountains of New Hampshire, p. 21-28. In H. W. Borns, Jr., P. LaSalle, and W. B. Thompson, eds., Late Pleistocene history of northeastern New England and adjacent Québec. Geological Society of America, Special Paper 197.

Goldthwait, J.W., 1916. Glaciation in the White Mountains of New Hampshire. Geological Society of America Bulletin, 27: 263-294.

1938. The uncovering of New Hampshire by the last ice sheet. American Journal of Science, fifth series, 36(215): 345-372.

Goldthwait, J.W., Goldthwait, L. and Goldthwait, R.P., 1951. The geology of New Hampshire: Part 1-surficial geology. New Hampshire State Planning and Development Commission, Concord, 81 p. and map.

Goldthwait, R.P. and Mickelson, D. M., 1982. Glacier Bay: A model for the deglaciation of the White Mountains in New Hampshire, p. 167-181. In G. J. Larson and B. D. Stone, eds., Late Wisconsinan glaciation of New England. Kendall/Hunt, Dubuque.

Hall, L. M., 1959. The geology of the St. Johnsbury quadrangle, Vermont and New Hampshire. Vermont Geological Survey, Bulletin 13, 105 p.

Hitchcock, C. H., 1878a. The geology of New Hampshire-Vol. III, Part III: Surface geology. E. A. Jenks, Concord, $386 \mathrm{p}$.

1878b. Atlas accompanying the report on the geology of New Hampshire. Julius Bien, New York, large folio, 17 sheets.

1897. The eastern lobe of the ice-sheet. The American Geologist, 20: 27-33.

1905. The geology of Littleton, p. 5-31. In J. R. Jackson, ed., History of Littleton, New Hampshire - Vol. I. University Press, Cambridge, Mass.

Koteff, C. and Pessl, F., Jr., 1981. Systematic ice retreat in New England. U.S. Geological Survey, Professional Paper 1179, 20 p.

1985. Till stratigraphy in New Hampshire: correlations with adjacent New England and Québec, p. 1-12. In H. W. Borns, Jr., P. LaSalle, and W. B. Thompson, eds., Late Pleistocene history of northeastern New England and adjacent Québec. Geological Society of America, Special Paper 197.

Koteff, C. and Larsen, F. D., 1989. Postglacial uplift in western New England: Geologic evidence for delayed rebound, p. 105-123. In S. Gregersen and P. W. Basham, eds., Earthquakes at North-Atlantic passive margins: Neotectonics and postglacial rebound. Kluwer, Amsterdam.

Lougee, R. J., n.d. (ca. 1930). The origin and occurrence of glacial washed deposits in the White Mountain region. Unpub. manuscript based on field work for New Hampshire Highway Department, 26 p. (Baker Library Special Collections, Dartmouth College).

1935. Time measurements of an ice readvance at Littleton, N. H Proceedings of the National Academy of Sciences, 21(1): 36-41.

1939. Geology of the Connecticut watershed, p. 131-149. In H. E. Warfel, ed., Biological survey of the Connecticut watershed. New Hampshire Fish and Game Department, Concord, Report 4.

1940. Deglaciation of New England. Journal of Geomorphology, 3: 189-217.

Lyons, J. B., Bothner, W. A., Moench, R. H. and Thompson, J. B., Jr., 1997. Bedrock geologic map of New Hampshire. U. S. Geological Survey, state geologic map, 2 sheets, scale: 1:250,000 and 1:500,000.

McDonald, B. C., 1968. Deglaciation and differential postglacial rebound in the Appalachian region of southeastern Québec. Journal of Geology, 76: 664-677.

Miller, N. G. and Thompson, G. G., 1979. Boreal and western North American plants in the late Pleistocene of Vermont. Journal of the Arnold Arboretum, 60(2): 167-218.

Moench, R. H., Boone, G. M., Bothner, W. A., Boudette, E. L., Hatch, N. L., Jr., Hussey, A. M., II and Marvinney, R. G., 1995. Geologic map of the Sherbrooke-Lewiston area, Maine, New Hampshire, and Vermont, United States, and Québec, Canada. U. S. Geological Survey, Map I-1898-D.
Occhietti, S., 1989. Quaternary geology of St. Lawrence Valley and adjacent Appalachian subregion, p. 350-389. In Chapter 4 of R. J. Fulton, ed., Quaternary Geology of Canada and Greenland. Geological Survey of Canada, Geology of Canada 1.

Parent, M. and Occhietti, S., 1988. Late Wisconsinan deglaciation and Champlain Sea invasion in the St. Lawrence Valley, Québec. Géographie physique et Quaternaire, 42(3): 215-246.

Rankin, D. W., 1994. Preliminary bedrock geologic map of parts of the Lower Waterford, Concord, Littleton, and Miles Pond 7.5-minute quadrangles, Vermont and New Hampshire. U.S. Geological Survey, Open-File Report 94-410, 28 p. and maps.

1995. The Littleton, Vermont-New Hampshire 15-minute quadrangle revisited: A progress report (abs.). Geological Society of America, Abstracts with programs, 27(1): 76 .

Ridge, J. C. and Larsen, F. D., 1990. Re-evaluation of Antevs' New England varve chronology and new radiocarbon dates of sediments from glacial Lake Hitchcock. Geological Society of America Bulletin, 102: 889-899.

Ridge, J. C., Thompson, W. B., Brochu, M., Brown, S. and Fowler, B. K., 1996. Glacial geology of the upper Connecticut Valley in the vicinity of the lower Ammonoosuc and Passumpsic Valleys of New Hampshire and Vermont, p. 309-339. In M. R. Van Baalen, ed., Guidebook to field trips in northern New Hampshire and adjacent regions of Maine and Vermont. Harvard University Department of Earth \& Planetary Sciences, Cambridge, Mass., guidebook to 88th Annual Meeting of New England Intercollegiate Geological Conference.

Rodrigues, C. G., 1992. Successions of invertebrate microfossils and the late Quaternary deglaciation of the central St. Lawrence Lowland, Canada and United States. Quaternary Science Reviews, 11: 503-534.

Shilts, W. W., 1981. Surficial geology of the Lac-Megantic area, Québec. Geological Survey of Canada, Memoir 397, 102 p.

Spear, R. W., 1989. Late Quaternary history of high-elevation vegetation in the White Mountains of New Hampshire. Ecological Monographs, 59(2): 125-151.

Stuiver, M., Grootes, P. M. and Braziunas, T. F., 1995. The GISP2 $\partial^{18} \mathrm{O}$ climate record of the past 16,500 years and the role of the sun, ocean, and volcanoes. Quaternary Research, 44: 341-354.

Thompson, W. B., 1998. Deglaciation of western Maine and the northern White Mountains (abs.). Geological Society of America, Abstracts with programs, $30(1): 79$.

Thompson, W. B. and Borns, H. W., Jr. (eds.), 1985. Surficial geologic map of Maine. Maine Geological Survey, 1:500,000-scale map.

Thompson, W. B. and Fowler, B. K., 1989. Deglaciation of the upper Androscoggin River valley and northeastern White Mountains, Maine and New Hampshire, p. 71-88. In R. D. Tucker and R. G. Marvinney, eds., Studies in Maine geology-Volume 6: Quaternary geology. Maine Geological Survey, Augusta.

Thompson, W. B., Fowler, B. K., Flanagan, S. M. and Dorion, C. C., 1996. Recession of the Late Wisconsinan ice sheet from the northwestern White Mountains, New Hampshire, p. 203-234. In M. R. Van Baalen, ed., Guidebook to field trips in northern New Hampshire and adjacent regions of Maine and Vermont. Harvard University Department of Earth \& Planetary Sciences, Cambridge, Mass., guidebook to 88th Annual Meeting of New England Intercollegiate Geological Conference.

Thompson, W. B., Dorion, C. C. and Fowler, B. K., 1997. Mode and chronology of deglaciation in western Maine and the northern White Mountains of New Hampshire. Canadian Quaternary Association, Program and abstracts for 8th Biennial Meeting, Montreal, p. 81-82.

Upham, W., 1878. Modified drift in New Hampshire, p. 3-176. In C.H. Hitchcock, The Geology of New Hampshire-Vol. III, Part III: Surface Geology. E. A. Jenks, Concord.

1904. Moraines and eskers of the last glaciation in the White Mountains. The American Geologist, 33: 7-14.

Wohlfarth, B., 1996. The chronology of the last termination: A review of radiocarbon-dated, high-resolution terrestrial stratigraphies. Quaternary Science Reviews, 15: 267-284. 
